\title{
Diel peroxy radicals in a semi-industrial coastal area: nighttime formation of free radicals
}

\author{
M. D. Andrés-Hernández ${ }^{1}$, D. Kartal ${ }^{1}$, J. N. Crowley ${ }^{2}$, V. Sinha ${ }^{2,3}$, E. Regelin ${ }^{2}$, M. Martínez-Harder ${ }^{2}$, V. Nenakhov ${ }^{1}$, \\ J. Williams ${ }^{2}$, H. Harder ${ }^{2}$, H. Bozem ${ }^{2}$, , W. Song ${ }^{2}$, J. Thieser ${ }^{2}$, M. J. Tang ${ }^{2}$, Z. Hosaynali Beigi ${ }^{2}$, and J. P. Burrows ${ }^{1}$ \\ ${ }^{1}$ Institute of Environmental Physics, University of Bremen, Bremen, Germany \\ ${ }^{2}$ Max Planck Institute for Chemistry, Mainz, Germany \\ ${ }^{3}$ Indian Institute of Science Education and Research Mohali, Department of Chemical Sciences, Sector 81, S.A.S. Nagar, \\ Manauli PO, Punjab 140306, India \\ *now at: Institute for Atmospheric Physics, University of Mainz, Mainz, Germany
}

Correspondence to: M. D. Andrés-Hernández (lola@iup.physik.uni-bremen.de)

Received: 25 June 2012 - Published in Atmos. Chem. Phys. Discuss.: 7 August 2012

Revised: 26 March 2013 - Accepted: 6 May 2013 - Published: 14 June 2013

\begin{abstract}
Peroxy radicals were measured by a PeRCA (Peroxy Radical Chemical Amplifier) instrument in the boundary layer during the DOMINO (Diel Oxidant Mechanisms In relation to Nitrogen Oxides) campaign at a coastal, forested site influenced by urban-industrial emissions in southern Spain in late autumn. Total peroxy radicals $\left(\mathrm{RO}_{2} *=\mathrm{HO}_{2}+\Sigma \mathrm{RO}_{2}\right)$ generally showed a daylight maximum between 10 and 50 pptv at 13:00 UTC, with an average of 18 pptv over the 15 days of measurements. Emissions from the industrial area of Huelva often impacted the measurement site at night during the campaign. The processing of significant levels of anthropogenic organics leads to an intense nocturnal radical chemistry accompanied by formation of organic peroxy radicals at comparable levels to those of summer photochemical conditions with peak events up to $60-80$ pptv. The $\mathrm{RO}_{2}$ production initiated by reactions of $\mathrm{NO}_{3}$ with organic trace gases was estimated to be significant, but not sufficient to account for the concentrations of $\mathrm{RO}_{2}$ * observed in air masses carrying high pollutant loading. The nocturnal production of peroxy radicals in those periods seems therefore to be dominated by ozonolysis of volatile organic compounds, in particular alkenes of industrial petrochemical origin.

$\mathrm{RO}_{2}$ * diurnal variations were consistent with $\mathrm{HO}_{2}$ measurements available at the site. $\mathrm{HO}_{2} / \mathrm{RO}_{2}$ * ratios generally varied between 0.3 and 0.6 , though on some occasions this ratio was likely to have been affected by instrumental artifacts (overestimated $\mathrm{HO}_{2}$ ) associated with high $\mathrm{RO}_{2}$ loads.
\end{abstract}

\section{Introduction}

Hydroperoxy $\left(\mathrm{HO}_{2}\right)$ and alkyl peroxy $\left(\mathrm{RO}_{2} ; \mathrm{R}=\right.$ organic chain) radicals are short-lived species involved in most of the photo-oxidation mechanisms taking place in the troposphere.

General features of the radical chemistry in the troposphere are determined by the presence of NO and volatile organic compounds (VOC), (Monks, 2005 and references therein) and comprise radical propagation mechanisms leading to formation of secondary oxidants like $\mathrm{O}_{3}$, and termination mechanisms i.e., radical recombination forming peroxides. $\mathrm{RO}_{2}$ and $\mathrm{HO}_{\mathrm{x}}\left(\mathrm{HO}_{\mathrm{x}}=\mathrm{HO}_{2}+\mathrm{OH}\right)$ are intermediates of many reactions and due to the balance between propagation and termination mechanisms it remains difficult to predict the actual radical levels and their effect on $\mathrm{O}_{3}$ production for a particular environment. Recent investigations indicate the impact of halogen chemistry and the existence of still unknown radical recycling mechanisms which might be crucial in explaining discrepancies between modelled and measured radical concentrations in some environments (Lelieveld et al., 2008; Dillon and Crowley, 2008; Hofzumahaus et al., 2009; Kubistin et al., 2010; Whalley et al., 2010, 2011).

Peroxy radicals can also be non-photochemically generated by reactions of organic species with $\mathrm{O}_{3}$ and $\mathrm{NO}_{3}$. As identified by Platt et al. (1990) nighttime $\mathrm{RO}_{2}$ production in coastal areas and under certain other specific conditions, like in forests or air masses affected by urban emission or biomass burning, can be as significant 
as photochemical production. For example, dimethyl sulfide (DMS) can react with $\mathrm{NO}_{3}$ (formed by the reaction of $\mathrm{NO}_{2}$ with $\mathrm{O}_{3}$ ) and produce significant levels of peroxy radicals (Sommariva et al., 2007). Nighttime chemistry in clean coastal and marine areas has generally been investigated with emphasis on the characterisation of $\mathrm{O}_{3}$ destruction events (Carslaw et al., 2002; Burkert et al., 2001a, 2003; Andrés Hernández et al., 2001). Under such conditions, relatively low nighttime mixing ratios of peroxy radicals have been measured, occasionally acquiring mixing ratios up to $25 \mathrm{pptv}$ (Salisbury et al., 2001; Fleming et al., 2006a).

Peroxy radical chemistry has generally received little attention in late autumn and winter periods when levels of solar radiation are low and photochemistry is less effective. However, some seasonality studies show that in winter significant oxidant levels are sustained while the net effect with respect to production of ozone is unclear (Harrison et al., 2006; Fleming et al., 2006b; Heard et al., 2004; Kanaya et al., 2008). Furthermore, diel measurements of peroxy radicals in complex environments are scarce yet important for a better understanding of the combined effect of natural and anthropogenic emissions on local and regional air quality.

The present paper reports on the radical chemistry observed during the DOMINO (Diel Oxidant Mechanisms In relation to Nitrogen Oxides) measurement campaign in late autumn and early winter 2008 in a photochemically complex environment. The role of day and night-time peroxy radicals was investigated by measuring peroxy radicals along with a suite of simultaneously measured chemical and meteorological parameters.

\section{Experimental}

The DOMINO measurement campaign took place at the Spanish atmospheric research station "El Arenosillo" $\left(37^{\circ} 05^{\prime} 58^{\prime \prime} \mathrm{N}, 6^{\circ} 44^{\prime} 17^{\prime \prime} \mathrm{W}\right)$ in November-December 2008. Due to its location in the nature reserve Doñana near the Atlantic Coast and close to the industrial and harbour area of the city of Huelva, the measurement site is periodically influenced by emissions of marine, biogenic, urban and industrial origin. In particular, the industrial area includes one of the most important European oil refineries and the largest pulp/paper mill of Spain. The measurement site has been described in detail in Crowley et al. (2011), Sinha et al. (2012), and Song et al. (2011).

The Institute of Environmental Physics of the University of Bremen (IUP-UB) participated in DOMINO with the measurement of the total sum of peroxy radicals, defined as $\mathrm{RO}_{2}^{*}=\mathrm{HO}_{2}+\Sigma \mathrm{RO}_{2}$ from 23 November to 11 December 2008. $\mathrm{RO}_{2}^{*}$ was measured using a DUALER (DUAl channeL peroxy radical chemical amplifiER) adapted for ground based measurements. This instrument is based on the PeRCA (Peroxy Radical Chemical Amplification) technique using two identical lines working in alternate modes, i.e., the am- plification mode resulting from the chemical conversion of $\mathrm{RO}_{2}^{*}$ into $\mathrm{NO}_{2}$ in a chain reaction above the $\mathrm{NO}_{2}$ background levels, and the background mode comprising $\mathrm{NO}_{2}$ and all $\mathrm{NO}_{2}$ sources other than radicals in the air sampled and up to the detector such as reaction of $\mathrm{NO}$ with $\mathrm{O}_{3}$ or the decomposition of PAN in the inlet, etc. (Kartal et al., 2010; Andrés-Hernández et al., 2010). $\mathrm{NO}_{2}$ is measured by detecting the chemiluminiscence of its reaction with luminol (3aminophthalhydrazide: $\mathrm{C}_{8} \mathrm{H}_{7} \mathrm{~N}_{3} \mathrm{O}_{2}$ ).

The DUALER methodology as first suggested by Cantrell et al. (1996) enables the calculation of $\mathrm{RO}_{2}^{*}$ mixing ratios from the difference between the simultaneous $\mathrm{NO}_{2}$ amplification signal of one of the detectors and the $\mathrm{NO}_{2}$ background signal of the other, provided the length of the amplification chain (i.e., chain length: CL) at the reactors is known and both detectors are well characterised. In contrast to the standard PeRCA methodology, the background signal does not need to be interpolated during the measurement of the amplification signal, which effectively increases the temporal resolution. Careful characterisation of both measurement lines (i.e., $\mathrm{NO}_{2}$ and $\mathrm{RO}_{2}^{*}$ calibrations of detectors and reactors, respectively) is therefore required in order to prevent biases in the measurement. Variations in the $\mathrm{NO}_{2}$ detector sensitivities are monitored by performing $\mathrm{NO}_{2}$ calibrations. Each detector was calibrated twice per day during DOMINO. Glass reactors were used during DOMINO as in previous ground based measurements (Burkert et al., 2001b, 2003; Andrés Hernández et al., 2001). The DUALER detection limit and accuracy are closely related to the relative humidity $(\mathrm{RH})$ dependency of the CL. Similar to Reichert et al. (2003) the CL was characterised in the laboratory for various RH. Continuous RH measurements at the site were used for the calculation of time dependent $\mathrm{CL}$ values and $\mathrm{RO}_{2}^{*}$ mixing ratios.

For the set up deployed within DOMINO the total $1 \sigma$ uncertainty of $1 \mathrm{~min} \mathrm{RO}_{2}^{*}$ averages is $30 \%$ and the detection limit 1-3 pptv for RH up to $50 \%$. Those values increase to $60 \%$ and 5-10 pptv, respectively, for RH between $70 \%$ and $90 \%$. Except when otherwise specified, the DUALER $\mathrm{RO}_{2}^{*}$ data presented in this work are 10 min Savitzky Golay averages. Due to instrumental calibrations $\mathrm{RO}_{2}^{*}$ data are not available on the 25 November.

As with most other DOMINO instruments, the DUALER double inlet for the $\mathrm{RO}_{2}^{*}$ measurements was located on the top of a $10 \mathrm{~m}$ scaffold approximately $4 \mathrm{~m}$ above the canopy and was connected to the instrumental rack placed in a container on the ground (Fig. 1).

\subsection{Other data}

A suite of chemical species was measured during DOMINO by different research institutes and has mostly been described in publications within a DOMINO special issue in this journal (http://www.atmos-chem-phys.org/specialissue246.html; Sörgel et al., 2011; Crowley et al., 2011; Sinha et al., 2012; 


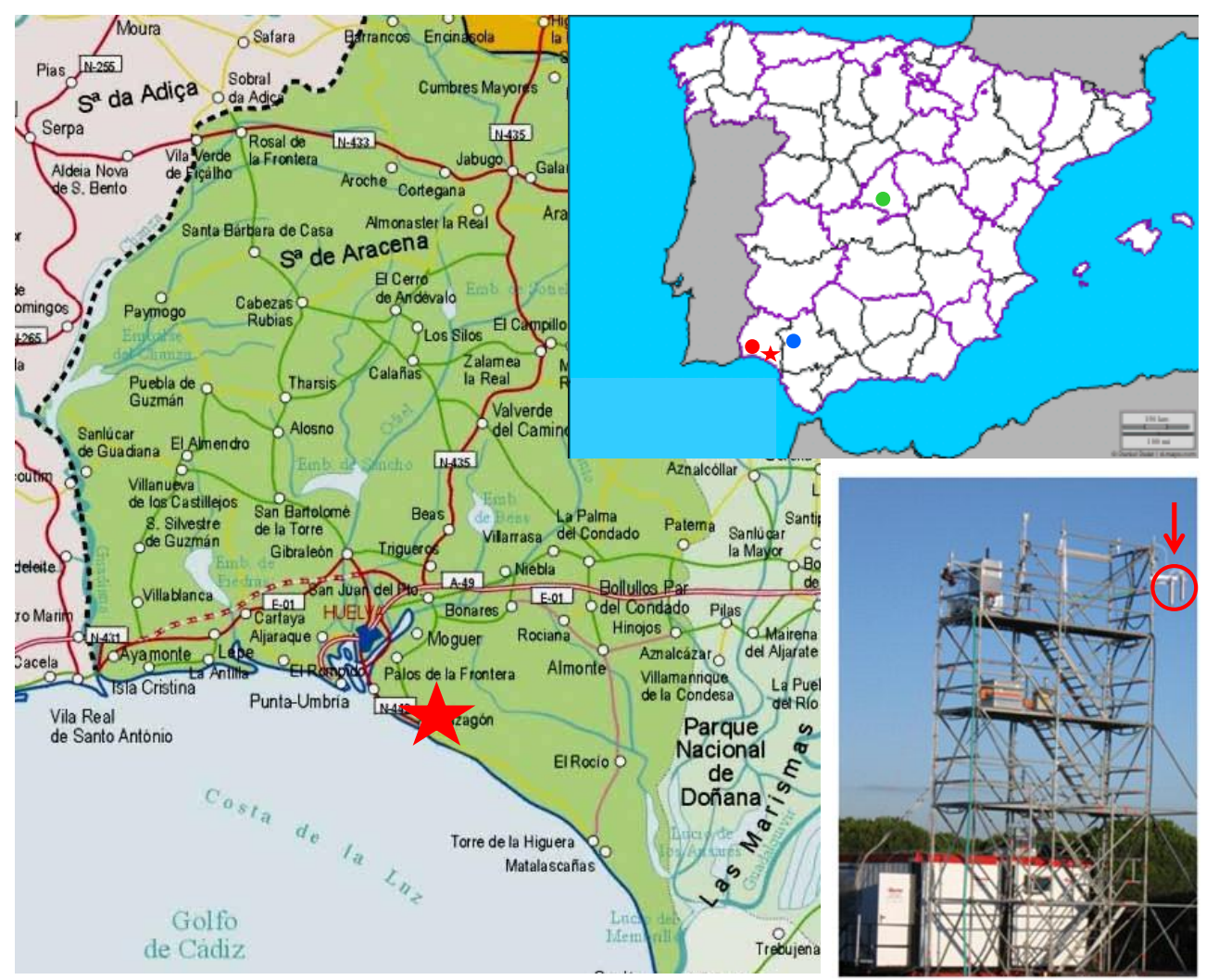

Fig. 1. Map of the site. El Arenosillo is highlighted by a red star. Main urban locations in the prevailing wind directions are also marked by dots: Huelva (red), Sevilla (blue) and Madrid (green). On the right side of the picture an arrow indicates the position of the DUALER inlet on the top of the $10 \mathrm{~m}$ scaffold for DOMINO measurements.

Diesch et al., 2012). Table 1 briefly summarises the main features of the instruments providing data for the present study.

$\mathrm{HO}_{2}$ radicals were measured by Fluorescence Assay with Gas Expansion (FAGE) with the HORUS instrument during DOMINO. A detailed description of the HORUS instrument can be found in Martinez et al. (2010). HORUS is based on the ATHOS instrument, for which a detailed study of possible interferences was performed by Ren et al. (2004). Recently Fuchs et al. (2011) reported on an $\mathrm{RO}_{2}$ interference for $\mathrm{HO}_{2}$ measurements by laser induced fluorescence (LIF) which is dependent upon detection cell design, residence time within the cell and NO level injected to titrate $\mathrm{HO}_{2}$ to $\mathrm{OH}$. This interference can be significant in conditions with very high VOC and low $\mathrm{NO}_{\mathrm{x}}$. The $\mathrm{HO}_{2}$ data presented here should be considered as an upper limit for $\mathrm{HO}_{2}$, which is henceforth defined as $\mathrm{HO}_{2}^{*}=\mathrm{HO}_{2}+\varepsilon \mathrm{RO}_{2}$; $\varepsilon$ was not quantified for HORUS during this campaign. Although $\varepsilon$ depends highly on the kind of $\mathrm{RO}_{2}$ present, values of $\varepsilon<0.2$ have been observed in two other ground-based measurement campaigns using the HORUS setup.

Local winds measured on the site at approximately inlet height (Diesch et al., 2012), were complemented by backward trajectories calculated using HYSPLIT for the classifi- cation of the air masses measured during DOMINO (Draxler and Rolph, 2011).

\section{Results and discussion}

The measurements reveal that the composition of the air masses arriving at the DOMINO site is the result of a complex mixture of weak biogenic (Song et al., 2012) and strong anthropogenic sources nearby. This is reflected in the high variability in the concentration level of most of the trace gases studied. $\mathrm{NO}_{\mathrm{x}}$ and VOC profiles were plume-like rather than having a structured reproducible diel pattern over the campaign. Time series of some selected trace gases are plotted in Figs. 2 and 3.

Generally, northerly wind directions coming from the NW and NE predominate (see a map of the location in Fig. 1). Prior to mixing with low wintertime biogenic emissions from the pine and eucalyptus forest in the national park (Song et al., 2012), the air masses were often exposed to fresh urban and industrial emissions of Huelva (the industrial area is located at $25 \mathrm{~km} \mathrm{NW}$ ) or Seville (at $70 \mathrm{~km} \mathrm{NE}$ ). Southwesterly winds associated with air masses of clean marine origin with occasional ship traffic occurred less frequently. 
Table 1. Main features of the DOMINO instruments used in this study. IUP-UB: Institute for Environmental Physics of the University of Bremen; MPI: Max Planck Institute; U. Mainz: University of Mainz; LIF (FAGE): Laser Induced Fluorescence (Fluorescence Assay with Gas Expansion); OA-CRD: Off Axis Cavity Ring Down; Chemilum./Phot. con.: Chemiluminiscence/Photolytical conversion; TD-GC-MS: Thermal Desorption Gas Chromatography - Mass Spectrometry; CRM-PTR-MS: Comparative Reactivity Method Proton Transfer Mass Spectrometry. $\left(^{*}\right) \mathrm{NO}_{3}$ was calculated from measured $\mathrm{N}_{2} \mathrm{O}_{5}$ and $\mathrm{NO}_{2}$ (see Crowley et al., 2011 for details).

\begin{tabular}{|c|c|c|c|c|c|c|}
\hline $\begin{array}{l}\text { Instrument/ } \\
\text { Institute }\end{array}$ & Principle & Species & $\begin{array}{l}\text { Time } \\
\text { Resolution (s) }\end{array}$ & $\begin{array}{l}\text { Detection } \\
\text { limit }\end{array}$ & Uncertainty & Reference \\
\hline $\begin{array}{l}\text { DUALER/ } \\
\text { IUP-UB }\end{array}$ & $\begin{array}{l}\text { Chemical } \\
\text { amplification }\end{array}$ & $\begin{array}{l}\mathrm{RO}_{2}^{*}=\mathrm{HO}_{2}+ \\
\Sigma \mathrm{RO}_{2}\end{array}$ & 60 & $\begin{array}{l}1-3 \text { pptv } \\
(\mathrm{RH} \leq 50 \%) \\
5-10 \mathrm{pptv} \\
(\mathrm{RH}>70 \%)\end{array}$ & $\begin{array}{l}30 \% \text { for } \\
\mathrm{RH} \leq 50 \% \\
60 \% \text { for } \mathrm{RH}>70 \%\end{array}$ & this paper \\
\hline $\begin{array}{l}\text { HORUS/ } \\
\text { MPI-Mainz }\end{array}$ & LIF (FAGE) & $\begin{array}{l}\mathrm{OH} \\
\mathrm{HO}_{2}\end{array}$ & 60 & $\begin{array}{l}0.037 \mathrm{pptv} \\
0.29 \mathrm{pptv}\end{array}$ & $\begin{array}{l}18 \% \\
18 \%\end{array}$ & Martinez et al. (2010) \\
\hline /MPI-Mainz & OA-CRD & $\mathrm{NO}_{3}, \mathrm{~N}_{2} \mathrm{O}_{5}$ & 5 & 5-7 pptv* & $35 \% *$ & Crowley et al. (2011) \\
\hline $\begin{array}{l}\text { CLD-790 SR } \\
\text { Ecophysics/MPI- } \\
\text { Mainz }\end{array}$ & $\begin{array}{l}\text { Chemilum./ } \\
\text { Phot. con. }\end{array}$ & $\mathrm{NO}, \mathrm{NO}_{2}$ & 1 & $\begin{array}{l}6 \mathrm{pptv} \\
8 \mathrm{pptv}\end{array}$ & $\begin{array}{l}5 \% \\
8 \%\end{array}$ & Hosaynali Beygi et al. (2011) \\
\hline $\begin{array}{l}\text { Airpointer/ } \\
\text { U. Mainz }\end{array}$ & $\begin{array}{l}\text { UV photometry } \\
\text { UV fluorescence }\end{array}$ & $\begin{array}{l}\mathrm{O}_{3} \\
\mathrm{SO}_{2}\end{array}$ & 6 & $<1 \mathrm{ppbv}$ & $1 \mathrm{ppbv}$ & Diesch et al. (2012) \\
\hline $\begin{array}{l}\text { Aero Laser AL 4021/ } \\
\text { MPI-Mainz }\end{array}$ & Hantzsch reaction & $\mathrm{HCHO}$ & 160 & $22 \mathrm{pptv}$ & $29 \%$ & Kelly and Fortune (1994) \\
\hline /MPI-Mainz & TD-GC-MS & VOC & 3600 & ca. 1 pptv & $15 \%$ & Song et al. (2011) \\
\hline /MPI-Mainz & CRM-PTR-MS & $\mathrm{OH}$ reactivity & 60 & $3.5 \mathrm{~s}^{-1}$ & $20 \%$ & Sinha et al. (2008) \\
\hline
\end{tabular}
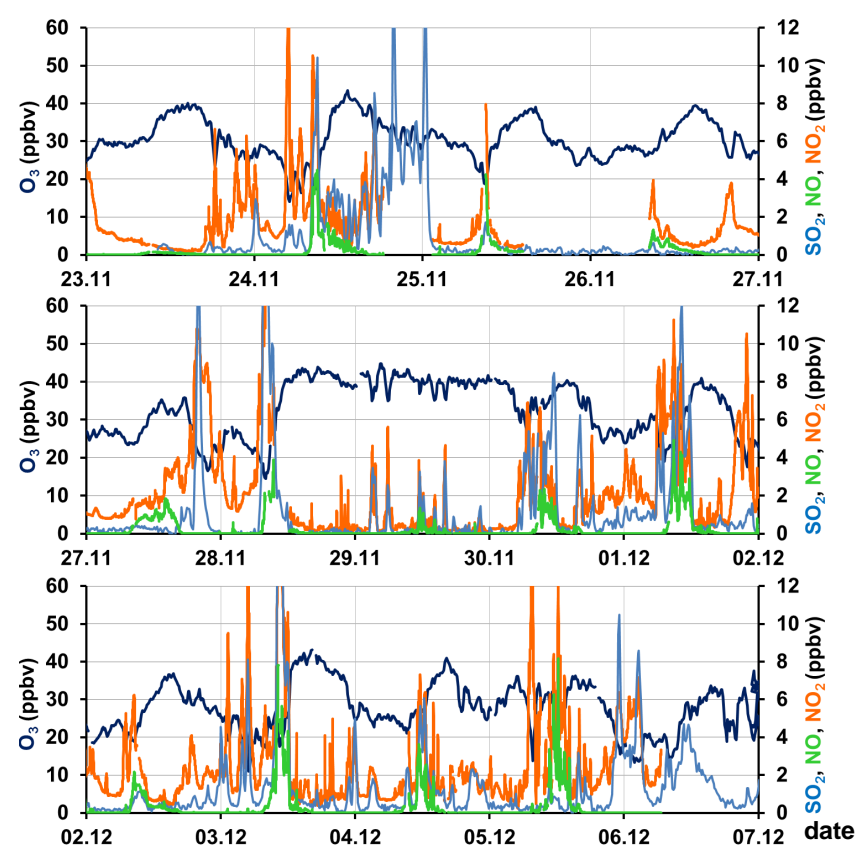

Fig. 2. Time series of selected trace gases measured during DOMINO.

Sinha et al. (2012) and Diesch et al. (2012) investigated the consistency in the air mass classification based on back trajectories and wind direction measured at the site during DOMINO and identified three major wind sectors: continental, comprising aged air masses coming from the interior of the Peninsula: $340-110^{\circ}$; urban-industrial, corresponding to city, port and industrial area of Huelva: $270-340^{\circ}$; and marine: $150-270^{\circ}$. Diesch et al. (2012) defined further subsectors: $65-82^{\circ}$ for air passing across Seville city, and $265-300^{\circ}$ for urban air masses having marine influence.

\subsection{General peroxy radical features during DOMINO}

Figure 4 depicts the $\mathrm{RO}_{2}^{*}$ time series measured during the campaign. Most diel periods showed a $\mathrm{RO}_{2}^{*}$ maximum at about 12:00-13:00 UTC reflecting photochemical $\mathrm{RO}_{2}^{*}$ production during daylight (note that the solar zenith is at 11:30 UTC; sunrise and sunset at 07:00 and 17:00 UTC, respectively) and significant production in the evening hours with $\mathrm{RO}_{2}^{*}$ generally reaching a maximum around midnight. $\mathrm{HO}_{2}^{*}$ radicals measured by the HORUS instrument are also included for comparison. $\mathrm{RO}_{2}^{*}$ and $\mathrm{HO}_{2}^{*}$ diurnal variations did mostly agree throughout the campaign. However, due to instrumental calibrations, nighttime $\mathrm{HO}_{2}$ data was not always available.

Variations in the short-lived species such as peroxy radicals, which are not transported significantly, are expected to be indicators of the in-situ composition of the air mass. The influence of meteorology and air mass type on radical concentrations was investigated by analysing the distribution of $\mathrm{RO}_{2}^{*}$ with respect to the local wind direction at the site (Fig. 5). For this, measurements on three periods of similar meteorology defined by Diesch et al. (2012) were examined together: until the 3 December sunny days, clear skies and stable nocturnal boundary layer prevailed except on the 

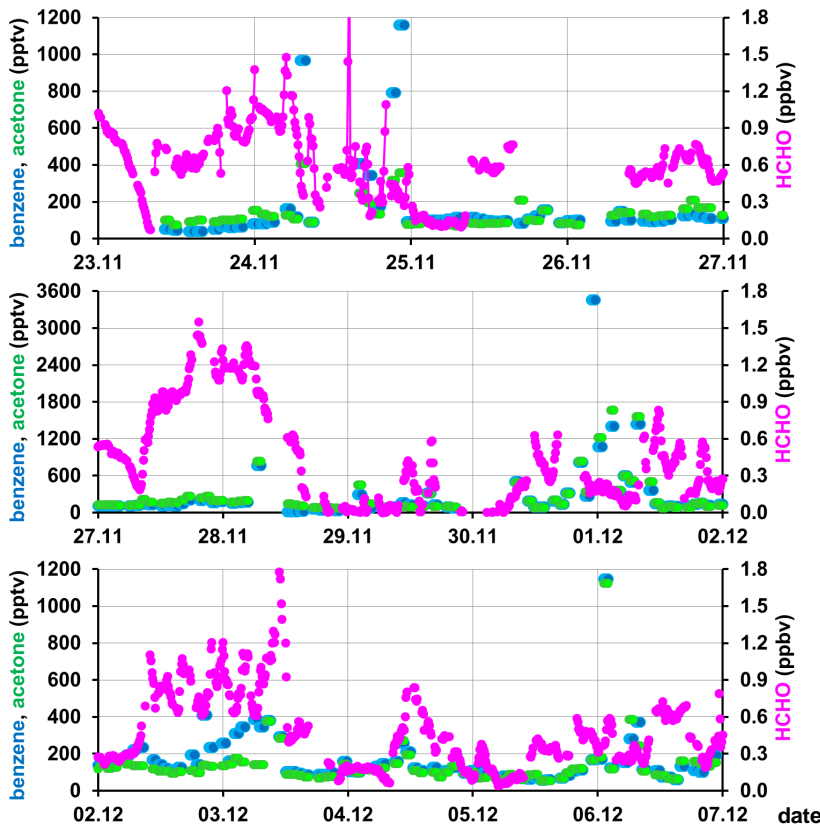

Fig. 3. Time series of selected trace gases measured during DOMINO. The scale of the y-axis is intendedly kept different for clarity.

28 November to 30 December when short rain periods occurred in the night. The rest of the campaign was cloudy with nearly constant temperature $\left(15-16^{\circ} \mathrm{C}\right)$ and relative humidity $(>70 \%)$ near the ground. Only mixing ratios measured at wind speed $>1.5 \mathrm{~ms}^{-1}$ are considered in order to rule out potential local interferences due to stagnant conditions at the site. Radicals measured during daylight periods (06:00-17:00 UTC, uppermost windroses) are separated from the rest.

As expected, highest $\mathrm{RO}_{2}^{*}$ mixing ratios are associated with clear sky stable conditions prevailing until the 28 November. For the rest of the campaign $\mathrm{RO}_{2}^{*}$ levels are lower (around 10-15 pptv daylight maximum).

No definite air mass dependence of the $\mathrm{RO}_{2}^{*}$ mixing ratios is expected in such a complex environment. VOC originating from different sources may provide different mixtures of precursors leading to the in-situ production of the $\mathrm{RO}_{2}^{*}$ measured. However, general patterns related to known chemistry (e.g., anti-correlation of $\mathrm{NO}$ with $\mathrm{RO}_{2}^{*}$ due to their common reaction, high $\mathrm{RO}_{2}^{*}$ at high organic loads accompanied by high $\mathrm{OH}$ reactivities, etc.) are expected to be identifiable. In that context, two features can be highlighted during DOMINO:

1. The highest daylight mixing ratios and tightest correlations between $\mathrm{RO}_{2}^{*}$ and $\mathrm{HO}_{2}^{*}$ (Fig. 6) were associated with air masses within the continental sector, which in turn were linked to clear sky conditions, favouring photochemical radical production, and,
2. enhanced nocturnal $\mathrm{RO}_{2}^{*}$ were observed mainly when the site was impacted with air masses coming from the urban-industrial sector transporting emissions from Huelva.

Concerning (1) the highest daytime $\mathrm{RO}_{2}^{*}$ maximum was found on the 23 and 24 November ( $47 \pm 10$ and $35 \pm 10$ pptv, respectively) when the highest temperatures of the campaign were reached $\left(T_{\max } 22^{\circ} \mathrm{C}\right.$ and $18^{\circ} \mathrm{C}$, respectively) as shown in Fig. 4. This positive relation with the temperature has been interpreted in previous work as an indirect effect driven by increases in the emission of radical precursors of biogenic origin with the temperature. In this context, pine trees tend not to generate monoterpenes instantaneously in response to light or temperature, but rather continuously through respiration with the monoterpene products being stored in resin ducts within the needle, the rate of release increasing with the temperature.

This is only partly reflected in the measurements. The monoterpenes $\alpha$-pinene, limonene, 1,8-cineole and camphor generally did not show any clear diel cycle. However, on the 24 November the mean mixing ratio of the sum of monoterpenes was $37 \pm 25 \mathrm{pptv}$, in contrast to $23 \pm 13$ pptv measured on the 23 November. This is about twice the level measured on all other clear days (Song et al., 2012). On the 23 November isoprene increased steadily and reached a 120 pptv maximum in the afternoon at 16:00 UTC, a value of about a factor 10 higher than the average during the whole measurement period. Song et al. (2012) interpret the delay in the isoprene maximum with respect to the temperature maximum as an indication of isoprene not being emitted from the local forest, but transported from other more distant forests and orange groves in the NE direction.

Concerning (2) the importance of local forest emissions in the nighttime measurements was further investigated. Despite differences in the measurement time resolution, $\mathrm{RO}_{2}^{*}$ and isoprene diel variations agreed reasonably, and nocturnal maxima were often accompanied by $\alpha$-pinene peak concentrations as on the 24 November at midnight. These nighttime maxima suggest the release of monoterpenes into a shallow nocturnal boundary layer. However, the $\mathrm{RO}_{2}$ production estimated from the ozonolysis of isoprene and $\alpha$-pinene can account for maximum $10 \%$ and $30 \%$, respectively, of the $\mathrm{RO}_{2}^{*}$ measured. The nocturnal $\mathrm{RO}_{2}^{*}$ production is discussed more in detail in Sect. 3.3.

\subsection{Diurnal photochemical radical production}

$\mathrm{RO}_{2}^{*}$ and $\mathrm{HO}_{2}^{*}$ measured during clear sky conditions, are summarised in Fig. 7. Except for the 24 November, air masses arriving on clear sky days at the site belong to the continental sector. Sinha et al. (2012) reported the highest average $\mathrm{OH}$ reactivity (defined as the total loss rate of $\mathrm{OH}$ radicals) in air masses from the continental sector, indicating high organic load which generally resulted in $\mathrm{NO}_{\mathrm{x}}$ limited $\mathrm{O}_{3}$ production at the site. This is confirmed by the variation 

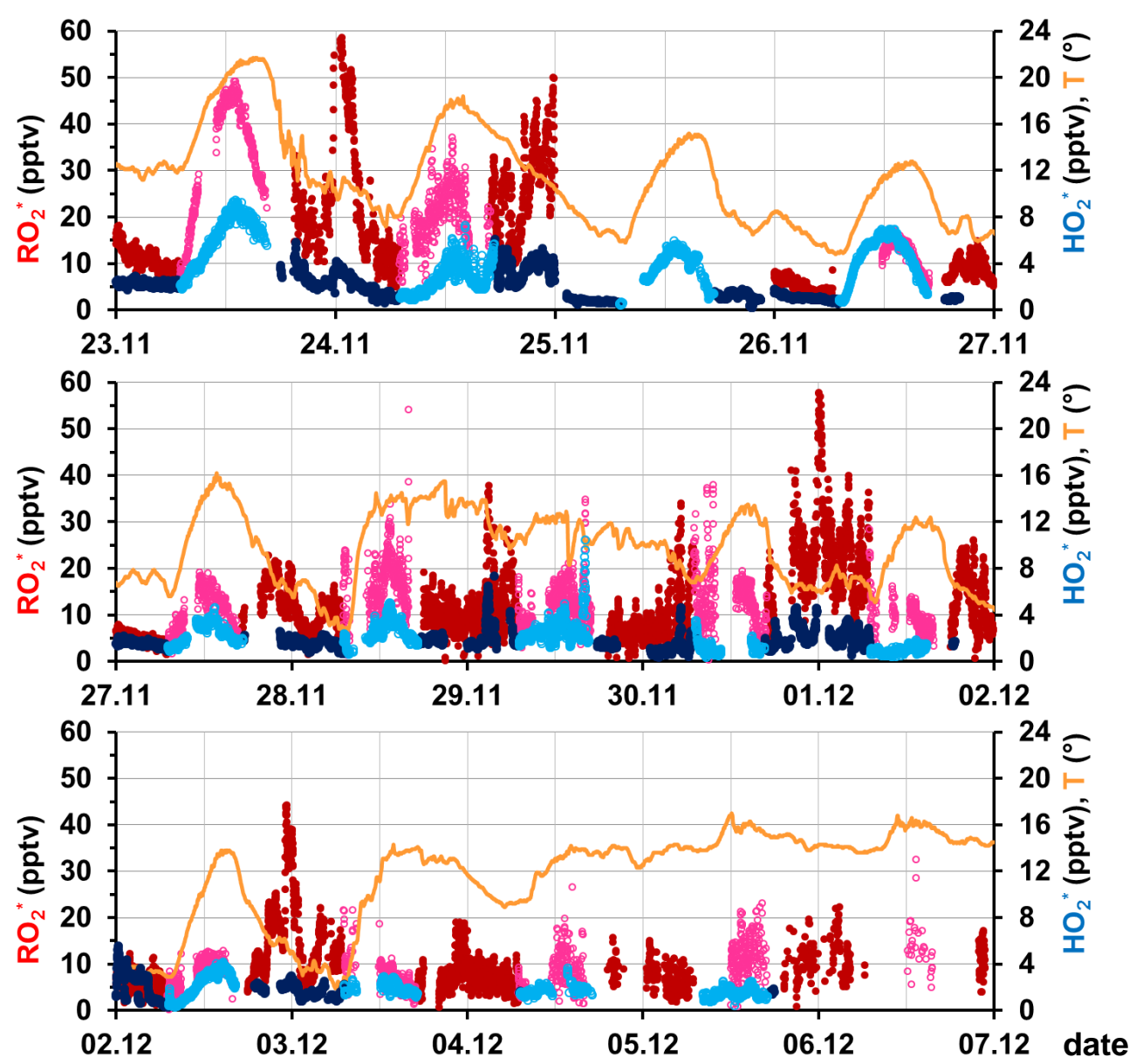

Fig. 4. DUALER-RO ${ }_{2}^{*}$ and HORUS-HO ${ }_{2}^{*}$ measured during DOMINO. Daylight (06:00-17:00 UTC) and nighttime periods are marked separately. Temperature is depicted as additional information.

with the wind sector of $\mathrm{O}_{3}$ and $\mathrm{NO}$ mixing ratios and $\mathrm{OH}$ reactivity on these days depicted in Fig. 8. Highest $\mathrm{OH}$ reactivity correlates with lowest $\mathrm{NO}$ and highest $\mathrm{RO}_{2}^{*}$ mixing ratios. As indicated in the previous section, the highest $\mathrm{RO}_{2}^{*}$ and $\mathrm{HO}_{2}$ diurnal mixing ratios were measured on the 23 November while NO remained below 200 pptv. At significant NO concentrations $\mathrm{RO}_{2}^{*}$ and $\mathrm{NO}$ are expected to be anticorrelated as a result of their reaction forming $\mathrm{NO}_{2}$. However, no clear correlation between $\mathrm{RO}_{2}^{*}$ and $\mathrm{NO}$ was observed during the campaign (see Fig. S1 in the Supplement). The variation of the $\mathrm{HO}_{2} / \mathrm{RO}_{2}$ ratio with $\mathrm{NO}$ is discussed more in detail in Sect. 3.4.

The measured $\mathrm{RO}_{2}^{*}$ were compared with estimations based on the deviation of the photostationary state (PSS) between $\mathrm{NO}, \mathrm{NO}_{2}$ and $\mathrm{O}_{3}$ (Leighton, 1961):

$$
\begin{aligned}
& \mathrm{NO}+\mathrm{O}_{3} \longrightarrow \mathrm{NO}_{2}+\mathrm{O}_{2} \quad k_{\mathrm{NO}+\mathrm{O}_{3}} \\
& \mathrm{NO}_{2} \stackrel{h v}{\longrightarrow} \mathrm{NO}+\mathrm{O} \quad J\left(\mathrm{NO}_{2}\right) \\
& \mathrm{O}_{2}+\mathrm{O} \stackrel{M}{\longrightarrow} \mathrm{O}_{3}
\end{aligned}
$$

Provided that $\mathrm{RO}_{2}^{*}$ radicals are the only oxidation agent causing the PSS deviations, the $\left[\mathrm{RO}_{2}^{*}\right]$ expected for midday periods with sufficient solar radiation can be calculated as:

$\left[\mathrm{RO}_{2}^{*}\right]_{\mathrm{PSS}}=\frac{J\left(\mathrm{NO}_{2}\right)}{k_{\mathrm{NO}+\mathrm{RO}_{2}^{*}}} \frac{\left[\mathrm{NO}_{2}\right]}{[\mathrm{NO}]}-\frac{k_{\mathrm{NO}+\mathrm{O}_{3}}}{k_{\mathrm{NO}+\mathrm{RO}_{2}^{*}}}\left[\mathrm{O}_{3}\right]$

where:

$\mathrm{NO}+\mathrm{RO}_{2}^{*}+\mathrm{O}_{2} \rightarrow \mathrm{NO}_{2}+\mathrm{HO}_{2}+\mathrm{RCOR}^{\prime}$

Calculated $\mathrm{RO}_{2}^{*} \mathrm{PSS}$ and measured $\mathrm{RO}_{2}^{*}$ mixing ratios are compared in Fig. 9 assuming $k_{\mathrm{NO}+\mathrm{RO}_{2}}=8.0 \times 10^{-12} \mathrm{~cm}^{3}$ molecule ${ }^{-1} \mathrm{~s}^{-1}$. The agreement is best on days under clear sky conditions, especially for the period of maximum solar radiation (between 10:00 and 16:00 UTC). However, except for the latter case, the PSS derived $\mathrm{RO}_{2}^{*}$ levels are higher than those measured by at least a factor of 2 . This has already been reported for several studies in different environments (Carpenter et al., 1998; Burkert et al., 2001b, and references herein; Mannschreck et al., 2004; Griffin et al., 2007). Significant uncertainties can be associated with the subtraction of two terms of similar magnitude in Eq. (1) which enhances 

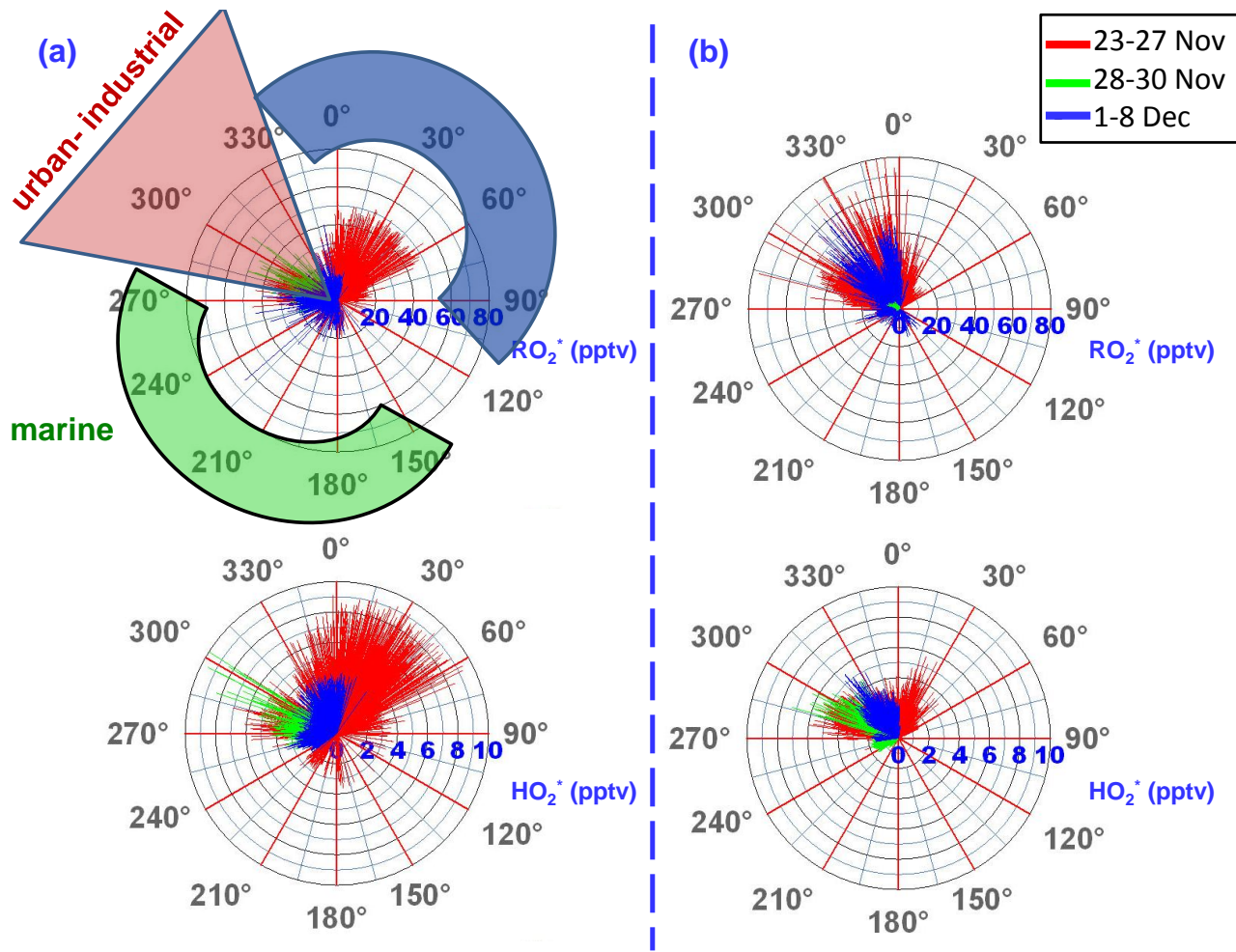

Fig. 5. Distribution of $\mathrm{RO}_{2}^{*}$ measured by DUALER according to local wind direction for the time periods of similar meteorology defined in Sect. 3.1: 23 to 27 November, 28 to 30 November and 1 to 7 December 2008. Data for (a) photochemical (06:00-17:00 UTC) and (b) non-photochemical (00:00-06:00 and 17:00 to 24:00 UTC) radical production are plotted separately. HO* measured by HORUS are also depicted for comparison (lowermost windroses). Wind sectors are indicated as additional information.

a)

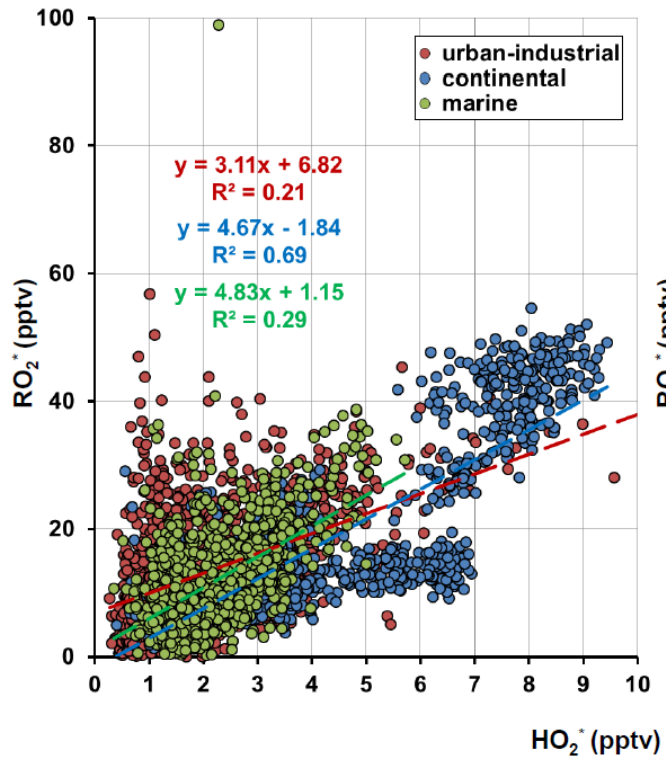

b)

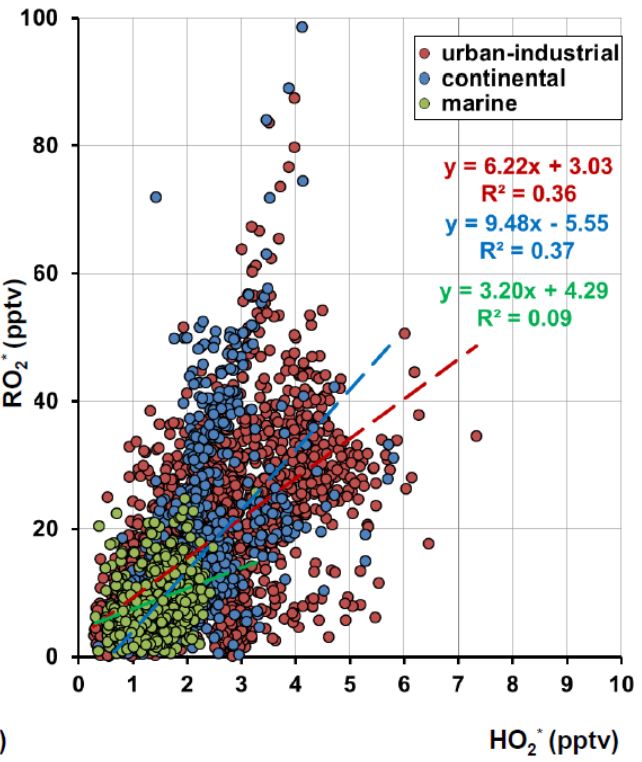

Fig. 6. $\mathrm{RO}_{2}^{*}$ to $\mathrm{HO}_{2}^{*}$ correlations for main wind sectors defined in the text. Data for (a) photochemical (06:00-17:00 UTC) and (b) nonphotochemical (00:00-06:00 and 17:00 to 24:00 UTC) radical production are plotted separately. Regression parameters are indicated as additional information. 

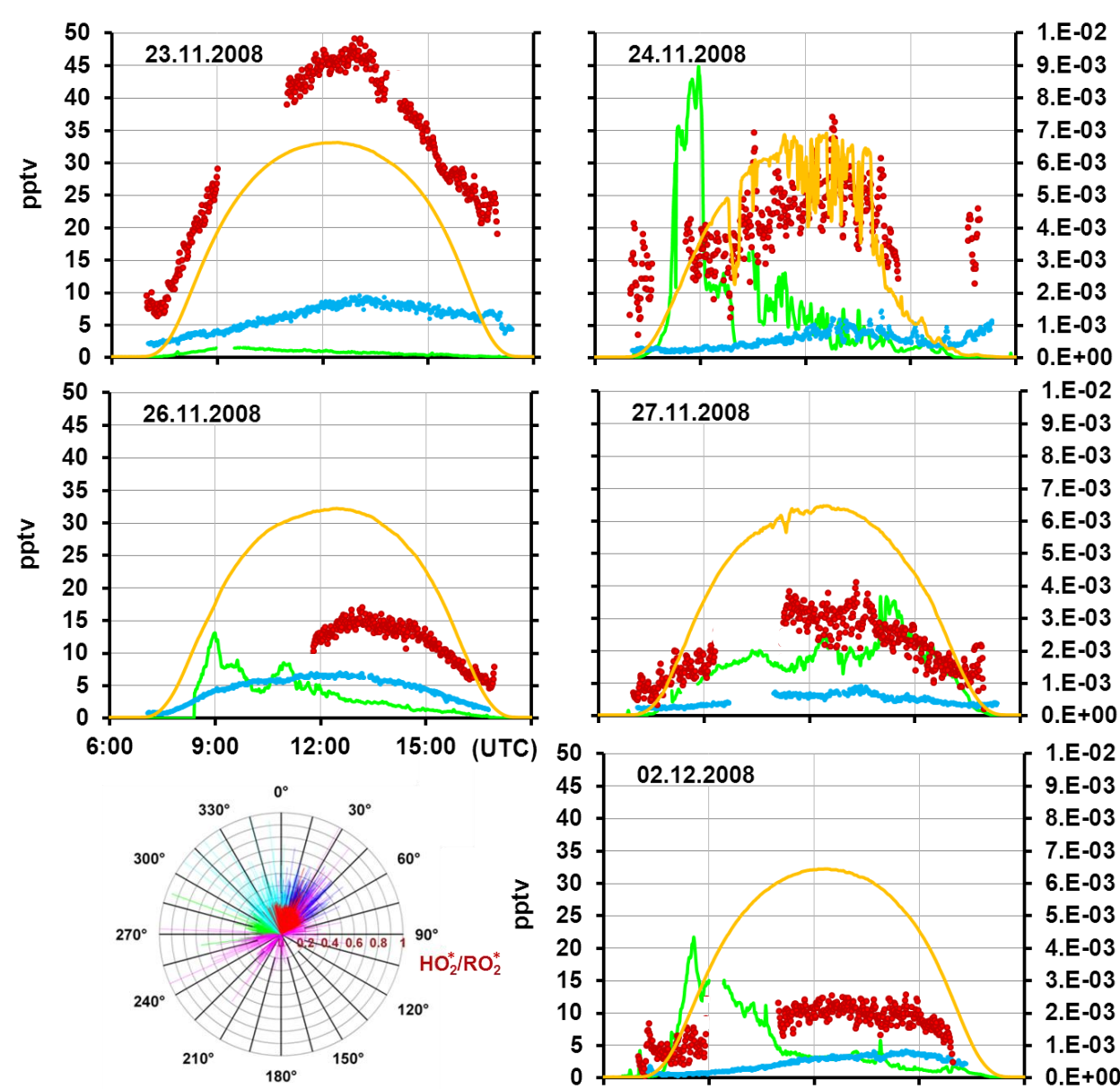

$-23.11-24.11-26.11-27.11-2.12$

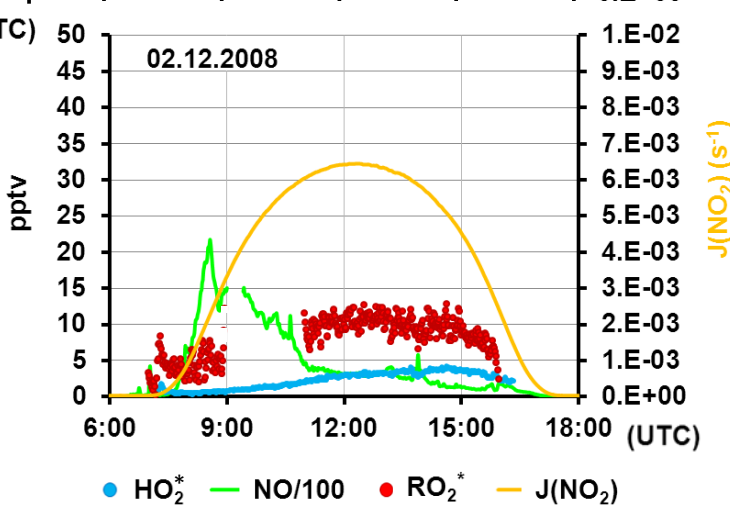

Fig. 7. Daylight $\mathrm{RO}_{2}^{*}$ and $\mathrm{HO}_{2}$ measured by DUALER and HORUS, respectively, under clear sky conditions during DOMINO. Periods without DUALER data corresponds with calibration of one of the $\mathrm{NO}_{2}$ detectors, in which the DUALER method of analysis cannot be applied (see text). The photolysis frequency $J\left(\mathrm{NO}_{2}\right)$ and $\mathrm{NO}$ data are also included as additional information. $\mathrm{RO}_{2}^{*}$ Savitzky-Golay 5 min averages are depicted without error bars to simplify the picture. The distribution of corresponding $\mathrm{HO}_{2} / \mathrm{RO}_{2}^{*}$ ratios according to the local wind direction is additionally plotted (bottom left).

the effect of instrumental errors. However, the agreement did not improve significantly when only considering those values for a $\mathrm{NO}_{2} / \mathrm{NO}$ ratio $<10$ as shown in Fig. 9.

As summarised by Sadanaga et al. (2003) further disagreement can be attributed to local sources and sinks of $\mathrm{NO}_{\mathrm{x}}$, to spatially inhomogeneous irradiance (Mannschreck et al., $2004)$, to the validity of $k_{\mathrm{NO}+\mathrm{RO}_{2}^{*}}$ for the sum of peroxy radicals, and to the meteorological conditions. In that context, the inlets for the DUALER and the NO/NO${ }_{\mathrm{x}}$ and $J_{\mathrm{NO}_{2}}$ instruments were very close together at the same height, on top of the measurement platform, so that the disagreement cannot be attributed to differences in the air mass sampled. The PSS assumption between species is only valid when $\mathrm{O}_{3}$ and solar radiation levels assure that the $\mathrm{NO}-\mathrm{NO}_{2}$ conversion occurs with a time constant of a few minutes. The difference observed under clear and non clear sky conditions is interpreted to be related to the uncertainty derived from $J_{\mathrm{NO}_{2}}$ short-term variations in the calculation of the PSS radicals. If only sunny days at the maximum irradiation time are considered, the PSS calculated values remain generally lower than the $\mathrm{RO}_{2}^{*}$ measured. This might be an indication that the $\mathrm{NO}_{2}$ photolysis within the air mass measured does not exactly correspond with the $J_{\mathrm{NO}_{2}}$ values measured on the top of the structure. As indicated by Mannschreck et al. (2004), the $\mathrm{NO}_{2}$ photolysis in air masses transported within a forest canopy can be substantially reduced due to reduced light penetration. The mixture of air parcels from within the forest and above might affect the PSS. 

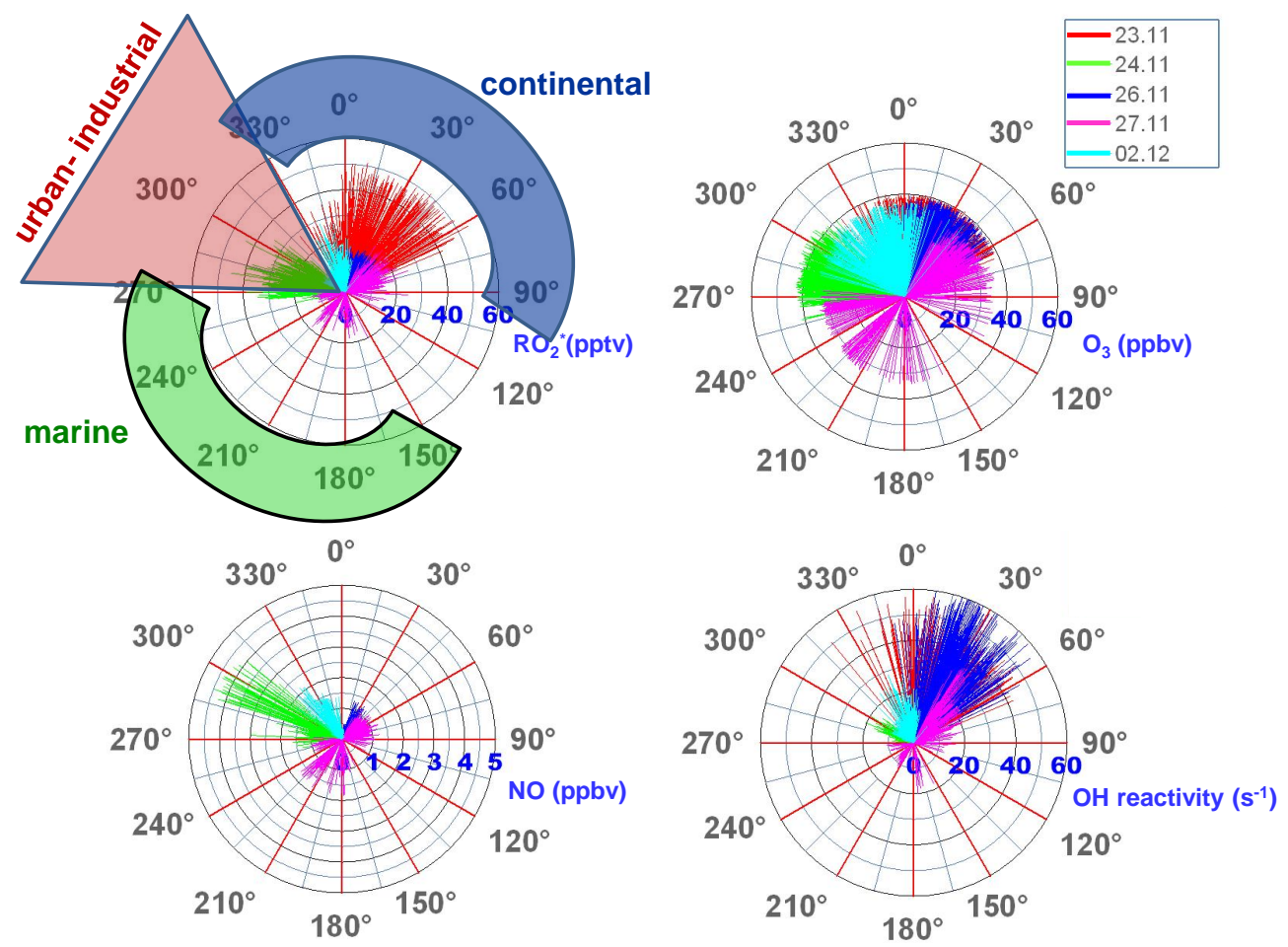

Fig. 8. Measured $\mathrm{RO}_{2}^{*}, \mathrm{O}_{3}$, $\mathrm{NO}$ mixing ratios and $\mathrm{OH}$ reactivity versus wind direction under clear sky conditions. Only periods of photochemical activity (06:00-17:00 UTC) are considered. Wind sectors are indicated as additional information.

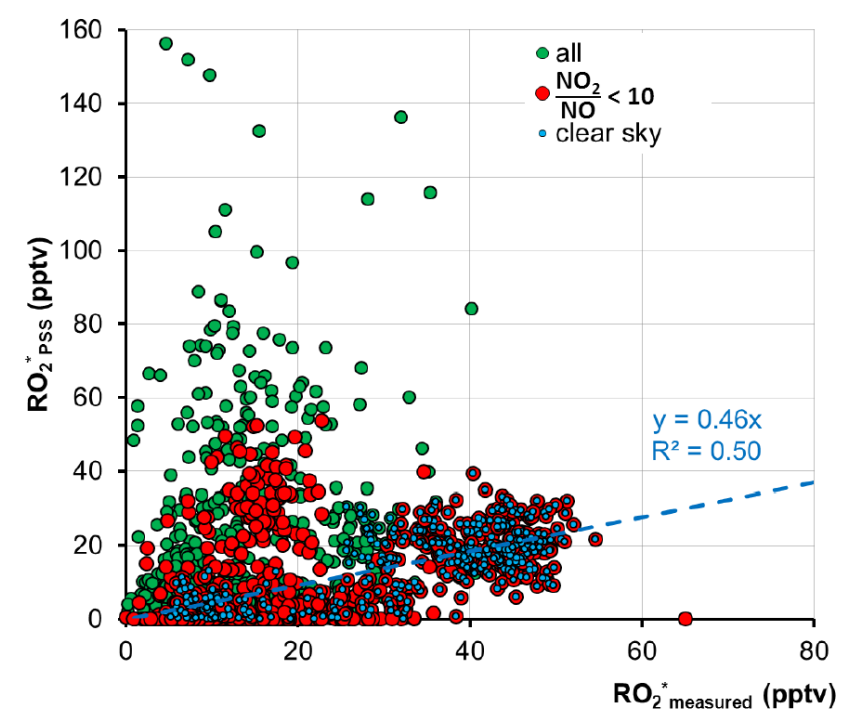

Fig. 9. $\mathrm{RO}_{2}^{*}$ mixing ratios calculated from the photostationary state (PSS) versus $\mathrm{RO}_{2}^{*}$ measured by the DUALER. Data for maximum insolation periods between 10:00 and 16:00 UTC (blue dots) and for $\mathrm{NO}_{2} / \mathrm{NO}<10$ (red dots) are highlighted.

\subsection{Nocturnal peroxy radicals}

Significant $\mathrm{RO}_{2}^{*}$ were observed in the night during DOMINO, as shown in Fig. 4. Nocturnal $\mathrm{RO}_{2}^{*}$ mixing ratios varied considerably (mean $47 \pm 53$ pptv) and on many diel cycles the $\mathrm{RO}_{2}^{*}$ levels were higher in the night than in daylight periods. This unusual situation may reflect a combination of low photochemical activity at this time of the year and abundant anthropogenic sources of radical precursors favouring nocturnal chemistry.

The nocturnal production of peroxy radicals can result from:

a. the gas phase reaction of $\mathrm{O}_{3}$ with alkenes. The reaction of $\mathrm{O}_{3}$ with alkenes is believed to occur via formation of Criegee intermediates the decomposition of which leads to $\mathrm{OH}, \mathrm{HO}_{2}$ and alkyl radicals in different yields depending on the structure of the alkene (Lightfoot et al., 1992). The $\mathrm{OH}$ thus generated will react with e.g., CO or hydrocarbons (Carter, 1990) to produce $\mathrm{RO}_{2}^{*}$. The ozonolysis of alkenes can also be of significance during daytime if the concentration of anthropogenic large alkenes is high (Paulson and Orlando, 1996), and if the $\mathrm{OH}$ formation from $\mathrm{O}_{3}$ photolysis is reduced due to low radiation levels in winter (Heard et al., 2004). If NO concentrations are sufficiently low, as in the night, the reactions between peroxy radicals can 
gain in importance and constitute the main sink, leading to production of peroxides, alcohols and carbonyls.

b. $\mathrm{NO}_{3}$ reactions (Platt et al., 1981, 1990; Wayne et al., 1991; Sadanaga et al., 2003; Brown and Stutz, 2012) with

- $\mathrm{HCHO}$ and longer chain aldehydes forming $\mathrm{HO}_{2}$ and $\mathrm{RO}_{2}$, respectively,

- alkenes, forming nitroxyalkylperoxy radicals. These can further react with $\mathrm{NO}_{2}, \mathrm{NO}_{3}$ and other $\mathrm{RO}_{2}^{*}$. This can lead to both positive and negative correlations between $\mathrm{NO}_{3}$ and $\mathrm{RO}_{2}$. Negative correlations have been observed in rural forested areas at very low $\mathrm{NO}$ levels, where $\mathrm{NO}_{3}$ reacts mainly with VOC while the $\mathrm{NO}_{3}$ production rate is independent of the VOC level (Mihelcic, 1993). Positive correlations in other environments have been attributed to the presence of $\mathrm{NO}$ which is a sink for both radicals (Geyer et al., 2003).

- DMS especially in coastal areas (Winer, 1984; Platt et al., 1990) leading to $\mathrm{CH}_{3} \mathrm{SCH}_{2} \mathrm{O}_{2}$ which can further react with $\mathrm{NO}_{3}$ to form $\mathrm{CH}_{3} \mathrm{~S}$ and $\mathrm{HCHO}$. Recently, Sommariva et al. $(2007,2009)$ simulated daytime and nighttime sources and sinks of radicals in the marine boundary layer and reported on the dominance of the DMS $+\mathrm{NO}_{3}$ chemistry leading occasionally to nighttime $\mathrm{RO}_{2}$ exceeding the daytime levels.

The mechanism for peroxy radical formation is highly uncertain (Finlayson-Pitts and Pitts, 2000; Holloway and Wayne, 2010, and references herein), and the relative contribution of the different routes to $\mathrm{RO}_{2}$ depends on the chemical environment. Bey et al. (2001a, b) used a two-layer box model to examine a broad range of $\mathrm{NO}_{\mathrm{x}}$, biogenic and anthropogenic VOC mixtures. According to their simulations, $\mathrm{NO}_{3}$ radicals can play a significant role in the primary formation of peroxy radicals in environments with significant $\mathrm{NO}_{\mathrm{x}}, \mathrm{O}_{3}$, and high levels of biogenic compounds, while at lower $\mathrm{NO}_{\mathrm{x}}$, ozonolysis reactions dominate the radical initiation. Any significant interconversion among $\mathrm{HO}_{\mathrm{x}}$ species (i.e., $\mathrm{HO}_{2}$ and $\mathrm{OH}$ ) at night is found to be driven by $\mathrm{RO}_{2}+\mathrm{NO}$ or $\mathrm{RO}_{2}+\mathrm{RO}_{2}$ reactions. In the rural and semirural cases investigated the $\mathrm{VOC}+\mathrm{NO}_{3}$ reactions initiate at the most $25 \%$ of the net $\mathrm{OH}$ production.

Only a few observations of nighttime peroxy radicals can be found in the literature and most of them have been measured in summer (Mihelcic et al., 1993; Kanaya et al., 2002; Platt et al., 2002; Martinez et al., 2003) or fall (Kanaya et al., 2007). Furthermore, $\mathrm{RO}_{2}^{*}$ in winter has been mostly measured in remote areas (Carslaw et al., 1997; Penkett et al., 1999; Fleming et al., 2006a, b) and some of those $\mathrm{RO}_{2}^{*}$ data are not corrected for the relative humidity interference reported by Mihele et al. $(1998,1999)$ and therefore not comparable with the present measurements. Kanaya et al. (2007) measured up to 5 pptv nocturnal $\mathrm{HO}_{2}$ in a pollution free coastal site in Japan. Modelling studies indicated a predominant radical production via reactions with monoterpenes emitted in the forest nearby. Within a seasonal study in an urban area ( $\mathrm{NO}_{\mathrm{x}}$ typically $10-30 \mathrm{ppbv}$ ) in Birmingham (England), Heard et al. (2004) reported high $\mathrm{OH}$ and $\mathrm{HO}_{2}$ radical levels in winter both during day and night. The corresponding modelling analysis of the radical budget (Emmerson et al., 2005) indicates that $\mathrm{HO}_{2}$ and $\mathrm{RO}_{2}$ formation at night involved primarily the reaction of $\mathrm{O}_{3}$ with alkenes, whilst the termination of $\mathrm{RO}_{2}$ was dominated by formation of peroxyacetyl nitrates. In contrast, $\mathrm{HO}_{2}$ mixing ratios measured in New York by Ren et al. (2006) were lower by a factor of $\sim 15$, with nocturnal values generally $<0.3 \mathrm{pptv}$. NOx/VOC ratios were higher in New York than in Birmingham with NO mostly $25-40 \mathrm{ppbv}$ in the night. In addition the radical production was slowed down by the low temperatures in New York down to $-25^{\circ} \mathrm{C}$. Modelling studies underestimated both diurnal and nocturnal $\mathrm{HO}_{2} . \mathrm{HO}_{\mathrm{x}}$ budget analysis showed that $\mathrm{HO}_{\mathrm{x}}$ production was dominated by the reaction of $\mathrm{O}_{3}$ with alkenes in the night.

In contrast Geyer et al. (2003) attributed $77 \%$ and $53 \%$ of the $\mathrm{RO}_{2}$ and $\mathrm{HO}_{2}$ nighttime production to the reaction of $\mathrm{NO}_{3}$ with terpenes, and $12 \%$ and $47 \%$ to ozonolysis, respectively. This study is based on measurements from a semiurban atmosphere in summer with high nighttime levels of $\mathrm{NO}_{2}$ and $\mathrm{O}_{3}$ (5-15 ppbv and 60-10 ppbv, respectively).

\subsubsection{Nocturnal $\mathrm{RO}_{2}^{*}$ production from $\mathrm{NO}_{3}$ chemistry}

In view of the results presented in the preceding section, the origin of the nocturnal $\mathrm{RO}_{2}^{*}$ measured during DOMINO was investigated. $\mathrm{NO}_{2}$ and $\mathrm{O}_{3}$ were present in the air mass arriving at night at the DOMINO site, favouring the formation of $\mathrm{NO}_{3} / \mathrm{N}_{2} \mathrm{O}_{5} . \mathrm{NO}_{3}$ up to $20 \mathrm{pptv}$ was calculated from the measurements of $\mathrm{N}_{2} \mathrm{O}_{5}$ and $\mathrm{NO}_{2}$ (Crowley et al., 2011). These data are broadly consistent with DOAS measurements close to the site. Sinks and sources of $\mathrm{NO}_{3}$ and $\mathrm{N}_{2} \mathrm{O}_{5}$ during DOMINO have been discussed in detail by Crowley et al. (2011).

During DOMINO dawn and evening periods no clear correlations between $\mathrm{RO}_{2}^{*}$ and $\mathrm{NO}_{3}$ were observed. This is expected to be the case if $\mathrm{NO}_{3}$ lifetimes are short due to an abundance of reactive VOCs. In addition (as indeed observed in this campaign, Crowley et al., 2010), $\mathrm{RO}_{2}$ vs. $\mathrm{NO}_{3}$ correlation can also be masked if other sources of $\mathrm{RO}_{2}$ radicals such as the ozonolysis of alkenes are present. This may be important at the anticipated high VOC levels in the emissions of the petrochemical industry nearby. Furthermore, the measurement of $\mathrm{RO}_{2}^{*}$ comprises a variable amount of $\mathrm{HO}_{2}$. In the presence of alkenes like dimethylbutene in concentrations significantly higher than NO, the respective reactions with $\mathrm{NO}_{3}$ can effectively compete and still enable $\mathrm{OH}$ production by the reaction of $\mathrm{HO}_{2}$ with $\mathrm{NO}_{3}$. $\mathrm{NO}$ was measured and generally lower than the detection limit of a few pptv. 
The NO measurements are described in more detail in Crowley et al. (2010).

The rate of production of $\mathrm{RO}_{2}$ from $\mathrm{NO}_{3}$ and organics during DOMINO can be estimated by considering the following simple reaction scheme:

$$
\begin{array}{ll}
\mathrm{NO}_{2}+\mathrm{O}_{3} \rightarrow \mathrm{NO}_{3}+\mathrm{O}_{2} & k_{\mathrm{NO}_{2}+\mathrm{O}_{3}} \\
\mathrm{NO}_{3}+\mathrm{VOC} \rightarrow \mathrm{RO}_{2} & k_{\mathrm{NO}_{3}+\mathrm{VOC}} \\
\mathrm{NO}_{3} \rightarrow \text { loss of } \mathrm{NO}_{3} & k_{\text {loss }}
\end{array}
$$

$k_{\text {loss }}$ is a first order term $\left(\mathrm{s}^{-1}\right)$ which includes all the losses of $\mathrm{NO}_{3}$ except the direct, gas phase reaction with organics (Reaction R6), and includes reaction with NO, indirect loss by aerosol uptake and dry deposition of $\mathrm{N}_{2} \mathrm{O}_{5}$ and the dry deposition of $\mathrm{NO}_{3}$. In a steady state analysis:

$$
\frac{\partial\left[\mathrm{NO}_{3}\right]}{\partial t}=
$$

$k_{\mathrm{NO}_{2}}+\mathrm{O}_{3}\left[\mathrm{NO}_{2}\right]\left[\mathrm{O}_{3}\right]-k_{\mathrm{NO}_{3}}+\operatorname{VOC}\left[\mathrm{NO}_{3}\right][\mathrm{VOC}]-k_{\text {loss }}\left[\mathrm{NO}_{3}\right]=0$

$\left[\mathrm{NO}_{3}\right]=\frac{k_{\mathrm{NO}_{2}+\mathrm{O}_{3}}\left[\mathrm{NO}_{2}\right]\left[\mathrm{O}_{3}\right]}{k_{\mathrm{NO}_{3}}+\operatorname{VOC}[\mathrm{VOC}]+k_{\text {loss }}}$

According to Crowley et al. (2010), $k_{\mathrm{NO}_{3}+\mathrm{VOC}}[\mathrm{VOC}]+k_{\text {loss }}$ is the total loss frequency, $f\left(\mathrm{NO}_{3}\right)$, calculated from the observed $\mathrm{NO}_{3}$ concentration and its production term $\left(k_{\mathrm{NO}_{2}+\mathrm{O}_{3}}\right.$ $\left[\mathrm{NO}_{2}\right]\left[\mathrm{O}_{3}\right]$ ); and $k_{\mathrm{NO}_{3}+\mathrm{VOC}}$ [VOC] is calculated by assuming that all losses of $\mathrm{NO}_{3}$ apart from those constrained by aerosol uptake of $\mathrm{N}_{2} \mathrm{O}_{5}$ or direct reaction of $\mathrm{NO}_{3}$ with $\mathrm{NO}$ or dry deposition of $\mathrm{NO}_{3}$ or $\mathrm{N}_{2} \mathrm{O}_{5}$ are due to reaction with organics.

Therefore, the $\mathrm{RO}_{2}$ production rate in pptvs ${ }^{-1}$ can roughly be calculated as:

$$
\frac{\partial\left[\mathrm{RO}_{2}\right]}{\partial t}=k_{\mathrm{NO}_{3}}+\operatorname{VOC}\left[\mathrm{NO}_{3}\right][\mathrm{VOC}]
$$

and substituting Eq. (3) into Eq. (4):

$$
\begin{aligned}
& \frac{\mathrm{k}_{\mathrm{NO}_{3}}+\mathrm{VOC}[\mathrm{VOC}]}{k_{\mathrm{NO}_{3}+\mathrm{VOC}}[\mathrm{VOC}]+k_{\text {loss }}} \times \mathrm{k}_{\mathrm{NO}_{2}+\mathrm{O}_{3}}\left[\mathrm{NO}_{2}\right]\left[\mathrm{O}_{3}\right]= \\
& \alpha k_{\mathrm{NO}_{2}+\mathrm{O}_{3}}\left[\mathrm{NO}_{2}\right]\left[\mathrm{O}_{3}\right]
\end{aligned}
$$

where $\alpha$ is the fraction of $\mathrm{NO}_{3}$ that is lost to organics. $\alpha$ can vary between $\sim 0$ (i.e., when $\mathrm{NO}$ is responsible for $\mathrm{NO}_{3}$ loss) and 1 (when the $\mathrm{NO}_{3}$ loss rates were dominated by reactions with organic trace gases). $\alpha$ was calculated for each time step and used to calculate the production rate of $\mathrm{RO}_{2}$ assuming that loss of $1 \mathrm{NO}_{3}$ (with organics) leads to $1 \mathrm{RO}_{2}$. On average (but depending on which scenario was used for the $\mathrm{N}_{2} \mathrm{O}_{5}$ heterogeneous loss, see Crowley et al., 2010) $\alpha$ was between 0.7 and 0.9 .

Nocturnal steady state mixing ratios of $\mathrm{RO}_{2}$ produced from $\mathrm{NO}_{3}$, i.e., $\left[\mathrm{RO}_{2}\right]_{\mathrm{nss}}$, can be calculated by assuming that, in the absence of $\mathrm{NO}$ at night, $\mathrm{RO}_{2}$ are uniquely lost by peroxy radical self reactions with a rate coefficient $k_{\mathrm{RO}_{2}}+\mathrm{RO}_{2}$ :

$\left[\mathrm{RO}_{2}\right]_{\mathrm{nss}}=\sqrt{ } \frac{\alpha k_{\mathrm{NO}_{2}+\mathrm{O}_{3}}\left[\mathrm{NO}_{2}\right]\left[\mathrm{O}_{3}\right]}{2 k_{\mathrm{RO}_{2}+\mathrm{RO}_{2}}}$

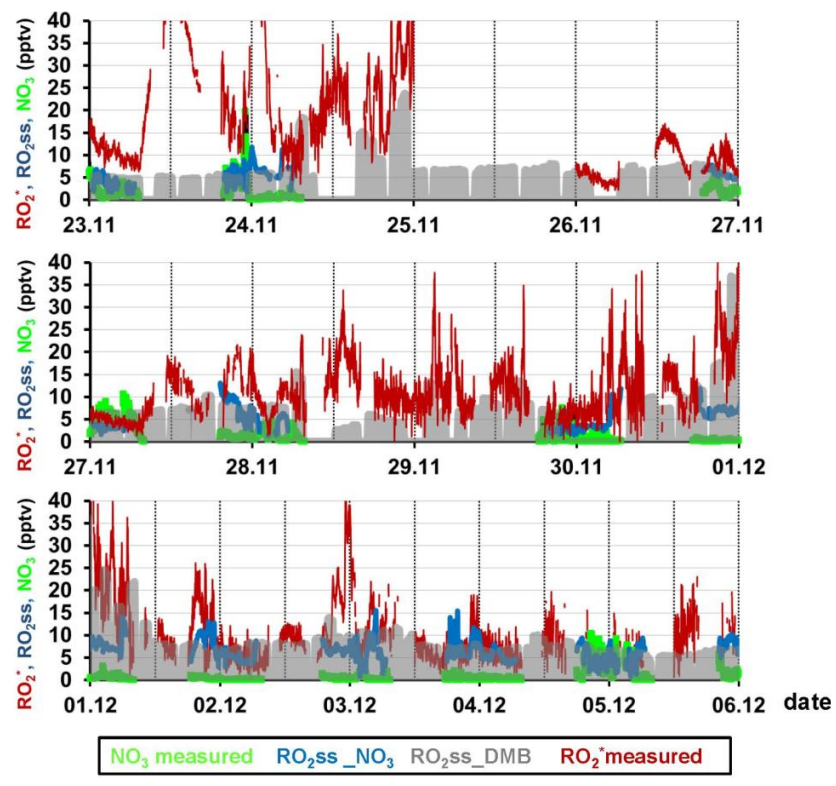

Fig. 10. Comparison between measured $\mathrm{RO}_{2}^{*}$ and calculated $\mathrm{RO}_{2 n s s}$ produced from $\mathrm{NO}_{3}$ (green) for $k_{\mathrm{RO}_{2}+\mathrm{RO}_{2}}=7.1 \times 10^{-12} \mathrm{~cm}^{3} \mathrm{molec}^{-1} \mathrm{~s}^{-1}$. Shadow areas represent the calculated $\mathrm{RO}_{2 \mathrm{ss}}$ from ozonolysis of DMB: dimethylbutene. $\mathrm{NO}_{3}$ mixing ratios are additionally plotted (green dots).

Based on Sander et al. (2011), Orlando and Tyndall (2012) and Calvert et al. (2011), two $k_{\mathrm{RO}_{2}}+\mathrm{RO}_{2}$ reaction rates were assumed for the DOMINO data: (a) $1.1 \times 10^{-11}$ and (b) $7.1 \times 10^{-12} \mathrm{~cm}^{3} \mathrm{molec}^{-1} \mathrm{~s}^{-1}$, representing a radical mixture dominated by $\mathrm{HO}_{2}+\mathrm{RO}_{2}$ or by $\mathrm{RO}_{2}+\mathrm{RO}_{2}$.

On average, and depending on the value assumed for $k_{\mathrm{RO}_{2}+\mathrm{RO}_{2}},\left[\mathrm{RO}_{2}\right]_{\mathrm{nss}}$ can account for between $47 \pm 16 \%$ and $54 \pm 17 \%$ of the $\mathrm{RO}_{2}^{*}$ on those nocturnal periods with available $\mathrm{NO}_{3}$ data. In Fig. 10, the $\left[\mathrm{RO}_{2}\right]_{\text {nss }}$ obtained for the case (b) are shown. The CL of the nocturnal peroxy radicals containing a nitrate group is not known for the unknown mixture of hydrocarbons reacting with $\mathrm{NO}_{3}$ during DOMINO. It is expected that these $\mathrm{RO}_{2}$ have a shorter CL than $\mathrm{CH}_{3} \mathrm{O}_{2}$ used for the $\mathrm{CL}$ calibrations. Therefore, if these peroxy radicals predominate in the air mass sampled, the $\mathrm{RO}_{2}^{*}$ calculated are underestimated and the contribution of the $\left[\mathrm{RO}_{2}\right]_{\text {nss }}$ above to the observed signal will be smaller. The nighttime $\mathrm{HO}_{2}^{*}$ mixing ratios measured did not exceed 8 pptv and normally varied between 2 and 6 pptv. Basically, $\left[\mathrm{RO}_{2}\right]_{\mathrm{nss}}$ cannot account for the organic peroxy radical fraction in the $\mathrm{RO}_{2}^{*}$ mixing ratios measured in periods associated with emissions arriving from the urban-industrial sector. This is the case on the 24 November, on the 30 November (18:00 to 06:00 UTC on the 1 December) and on the 2 December (18:00 to 02:00 UTC). The highest mixing ratios of anthropogenic VOC and secondary oxidation products like acetone and formaldehyde were also observed during these high nocturnal $\mathrm{RO}_{2}$ events. Other VOC leading to peroxy radicals by ozonolysis can presumably be present as well. 
In particular, on the 30 November around midnight benzene and acetone are close to $3.5 \mathrm{ppbv}$ (see Fig. 3). Measurements of anthropogenic alkenes would have greatly aided the interpretation of results, but were not available due to instrument failure. The potential contribution of ozonolysis of alkenes to the observed nocturnal $\mathrm{RO}_{2}^{*}$ is discussed in more detail in Sect. 3.3.2.

Crowley et al. (2011) speculate on the potential importance of the $\mathrm{NO}_{3}$ induced oxidation of reduced sulphur compounds emitted by the paper mill in the Huelva industrial area during DOMINO, producing $\mathrm{HCHO}, \mathrm{SO}_{2}$ and $\mathrm{RO}_{2}$, as reported by Jensen et al. (1992). In particular, during the event on the 24 November, $\mathrm{RO}_{2}^{*}$ reached the highest nocturnal value (90 pptv) and HCHO $1.5 \mathrm{ppbv}$ at the time a plume of $\mathrm{SO}_{2}$ (3 ppbv) arrived at the site. Similarly, on the $2 \mathrm{De}-$ cember 6 ppbv $\mathrm{SO}_{2}, 1$ ppbv $\mathrm{HCHO}, 1$ ppbv PAN and $45 \mathrm{pptv}$ $\mathrm{RO}_{2}^{*}$ were concurrently measured. However, $\mathrm{SO}_{2}$ remained $\leq 1 \mathrm{ppbv}$ during the event on the 30 November in the evening while on the 3 December at dawn $\mathrm{SO}_{2}$ plumes up to $8 \mathrm{ppbv}$ do not seem to disturb the agreement between $\left[\mathrm{RO}_{2}\right]_{\mathrm{nss}}$ and $\mathrm{RO}_{2}^{*}$ measured (see Fig. 2). The latter seems to be the case when the $\mathrm{SO}_{2}$ are accompanied by $\mathrm{NO}_{2}$ plumes with winds of marine origin, indicating another source of emissions. It is not obvious how the DUALER responds to peroxy radicals generated from reaction of $\mathrm{NO}_{3}$ with sulphurous precursors.

\subsubsection{Nocturnal $\mathrm{RO}_{2}^{*}$ production from ozonolysis}

As mentioned above, neither the mixture nor the diurnal behaviour of anthropogenic alkenes during the DOMINO campaign are known. In the case of ozonolysis a simple calculation, like for $\mathrm{NO}_{3}$ in Sect. 3.3.1. is not possible as the chemical lifetime of $\mathrm{O}_{3}$ with respect to reaction with olefins can not be straightforwardly defined and the reaction rates of olefins with $\mathrm{O}_{3}$ are very variable. However, the potential importance of ozonolysis reactions was investigated by assuming an alkene mixture from the Houston petrochemical plume as published by Leuchner et al. (2010). Benzene measurements in Houston and DOMINO were used as reference and dimethylbutene (DMB), methylpentene (MP) and butadiene (BD) mixing ratios were normalised to the benzene measured ratios, on the basis of their relative proportion to benzene in the Houston plume, i.e., $18 \%, 5 \%$ and $100 \%$, respectively. This implies that benzene and those olefins are assumed to have during DOMINO a common source and/or identical diurnal behaviour. According to these calculations, average mixing ratios were assumed to be $35 \pm 25 \mathrm{pptv}$ for DMB, $10 \pm 7 \mathrm{pptv}$ for MP, and $192 \pm 140 \mathrm{ppt}$ for BD, with 623 pptv, 173 pptv and 3460 pptv maximum mixing ratios, respectively. Expected $\mathrm{RO}_{2}$ steady state mixing ratios were calculated for each alkene $\left(\mathrm{Alk}_{i}\right)$ by using the $\mathrm{O}_{3}$ measured during DOMINO, according to:

$\left[\mathrm{RO}_{2}\right]_{\mathrm{SS}}=\sqrt{ } \frac{\mathrm{k}_{\mathrm{O}_{3}+\mathrm{Alk}_{i}}\left[\mathrm{O}_{3}\right]\left[\mathrm{Alk}_{i}\right]}{2 k_{\mathrm{RO}_{2}+\mathrm{RO}_{2}}}$
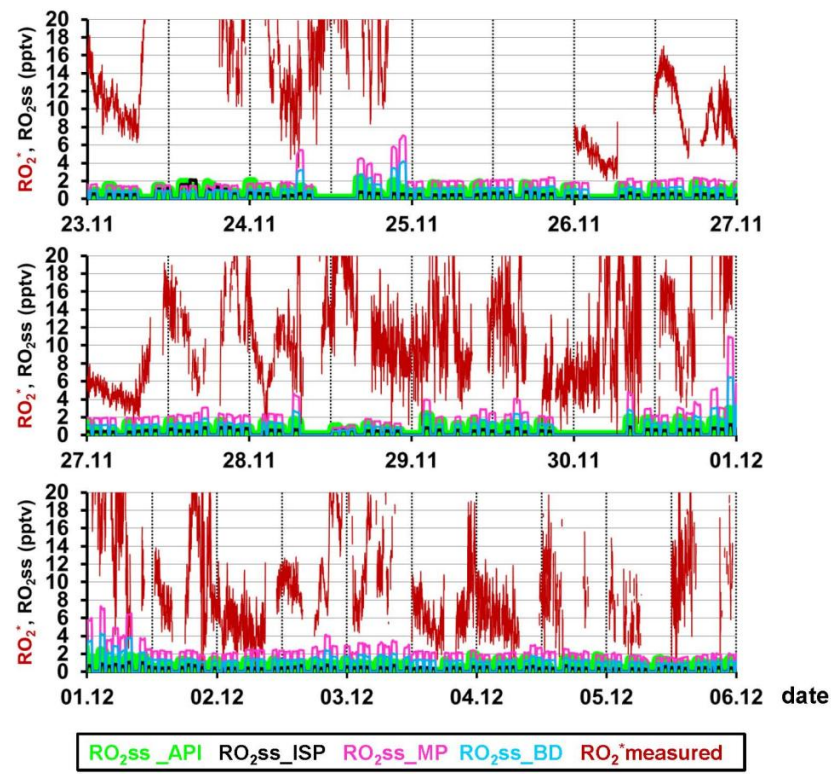

Fig. 11. Comparison between measured $\mathrm{RO}_{2}^{*}$ and calculated $\mathrm{RO}_{2 \mathrm{ss}}$ from ozonolysis of different alkenes: API: $\alpha$-pinene; ISP: isoprene; BD: butadiene, and MP: methylpentene.

With $\quad k_{\mathrm{DMB}+\mathrm{O}_{3}}=1.13 \times 10^{-15} \mathrm{~cm}^{3}$ molecule $^{-1} \mathrm{~s}^{-1}$, $k_{\mathrm{MP}+\mathrm{O}_{3}}=5.6 \times 10^{-16} \mathrm{~cm}^{3}$ molecule $^{-1} \mathrm{~s}^{-1}$,

$k_{\mathrm{BD}+\mathrm{O}_{3}}=6.3 \times 10^{-18} \mathrm{~cm}^{3}$ molecule ${ }^{-1} \mathrm{~s}^{-1}$, and the same $\mathrm{RO}_{2}+\mathrm{RO}_{2}$ reaction rates used for the estimation of steady state mixing ratios of $\mathrm{RO}_{2}$ produced from $\mathrm{NO}_{3}$ (i.e., (a) $1.1 \times 10^{-11}$ and (b) $7.1 \times 10^{-12} \mathrm{~cm}^{3} \mathrm{molec}^{-1} \mathrm{~s}^{-1}$ ). These calculated $\mathrm{RO}_{2 \text { ss }}$ produced from ozonolysis are compared in Figs. 10 and 11 with the $\mathrm{RO}_{2}^{*}$ measured. Except on the 23 November the $\mathrm{RO}_{2 \mathrm{ss}}$ calculated for the measured isoprene and $\alpha$-pinene represents in average around $4 \%$ and $8 \%$, respectively of the total $\mathrm{RO}_{2 \mathrm{ss}}$ calculated for the alkene mixture assumed.

The sum of the $\mathrm{RO}_{2 \mathrm{ss}}$ calculated can be considered as an upper limit. The results show that the $\mathrm{RO}_{2 \mathrm{ss}}$ calculated from a plume of these alkene characteristics arriving at the site would account for the average of $59 \% \pm 19 \%$ or $68 \% \pm 20 \%$ of the $\mathrm{RO}_{2}^{*}$ observed most of the nights for $k_{\mathrm{RO}_{2}+\mathrm{RO}_{2}} 1.1 \times 10^{-11} \mathrm{~cm}^{3} \mathrm{molec}^{-1} \mathrm{~s}^{-1}$ or $7.1 \times 10^{-12} \mathrm{~cm}^{3} \mathrm{molec}^{-1} \mathrm{~s}^{-1}$. Dimethylbutene appeared to be the most important alkene for $\mathrm{RO}_{2}^{*}$ generation.

In addition, most events associated with emissions arriving from the urban-industrial sector (e.g., on the nights of 24 November, 30 November, and 2 December) could be explained this way. On the 24 December at dawn, however, both alkenes and $\mathrm{NO}_{3}$ can each only account for about $25 \%$ of the $\mathrm{RO}_{2}^{*}$ measured.

In summary, emissions from the industrial area of Huelva often impacted the measurement site at night during the campaign. The processing of significant levels of anthropogenic organics leads to an intense nocturnal radical 
chemistry accompanied by the formation of organic peroxy radicals at concentration levels comparable to those of summer photochemical conditions. Using the simplified chemical approach presented in Sect. 3.3.1, it can be concluded that the nocturnal formation of peroxy radicals from $\mathrm{NO}_{3}$ and VOC is significant but not always sufficient to reproduce the $\mathrm{RO}_{2}^{*}$ measurements in industrial pollution events. The $\mathrm{RO}_{2}^{*}$ levels observed in those periods might be explained by the ozonolysis of a mixture of alkenes of industrial petrochemical origin simultaneously emitted with the benzene measured at the site.

\subsection{Diel $\mathrm{HO}_{2}^{*} / \mathrm{RO}_{2}^{*}$ ratio and $\mathrm{OH}$ reactivity}

The $\mathrm{HO}_{2} / \mathrm{RO}_{2}$ ratio for daylight and nighttime periods was calculated from the $\mathrm{RO}_{2}^{*}$ DUALER and $\mathrm{HO}_{2}^{*}$ HORUS measurements during DOMINO, and the distribution versus wind direction was further investigated. As pointed out in Sect. 3.1., data for wind speed $<1.5 \mathrm{~m} \mathrm{~s}^{-1}$ have not been considered in the analysis in Fig. 5 in order to rule out any effect of stagnant conditions.

The calculated $\mathrm{HO}_{2} / \mathrm{RO}_{2}$ ratio generally varied between 0.3 and 0.8 , with higher values for the continental and urban sectors on the 26 and 29 November, and on the 2 and 3 December. This could indicate a more effective conversion of $\mathrm{RO}_{2}$ in $\mathrm{HO}_{2}$ in anthropogenic regimes. However, as mentioned above, there is neither a significant correlation between $\mathrm{RO}_{2}^{*}$ and $\mathrm{NO}$, which was close to the detection limit most of the nights, nor $\mathrm{NO}_{\mathrm{x}}$. Figure 12 depicts measured $\mathrm{HO}_{2}^{*}$ vs. $\mathrm{RO}_{2}^{*}$ for different $\mathrm{NO}$ missing ratios measured during DOMINO. During the day $\mathrm{HO}_{2}^{*} / \mathrm{RO}_{2}^{*}$ generally varies around 0.15 for $\mathrm{NO}<1 \mathrm{ppb}$ and presents no correlation at higher NO mixing ratios. In the night, NO remains mostly below $0.1 \mathrm{ppb}$ and the $\mathrm{HO}_{2}^{*} / \mathrm{RO}_{2}^{*}$ is significantly lower (Fig. 13b). It can be concluded that the radical chemistry especially in the night was mainly determined by the abundance, nature and chemistry of the VOC acting as peroxy radical precursors in the air mass.

The ratio $\mathrm{HO}_{2}^{*} / \mathrm{RO}_{2}^{*}$ occasionally reached values $>1$ for wind directions around $260^{\circ}$ and $330^{\circ}$ where the air mass was affected by the emissions of the industrial and port areas of Huelva, as on the 2 December night and 3 December daytime periods. As $\mathrm{RO}_{2}^{*}$ comprises $\mathrm{HO}_{2}$ this must be an artifact related with the use of data from two different instruments which can be subject to different experimental interferences. As mentioned in Sect. 2.1., Fuchs et al. (2011) recently reported interferences in the $\mathrm{HO}_{2}$ measurement by LIF instruments with chemical conversion of $\mathrm{HO}_{2}$ to $\mathrm{OH}$ by adding $\mathrm{NO}$, like HORUS, of some $\mathrm{RO}_{2}$ produced by alkenes and aromatics. As a consequence, and especially in polluted environments and areas with large emissions of alkenes or aromatics, the nominal $\mathrm{HO}_{2}$ mixing ratios measured by LIF can actually be the sum of $\mathrm{HO}_{2}$ and a significant fraction of $\mathrm{RO}_{2}$ mixing ratios. As stated in Sect. 2.1., the effect of this interference depends on the measurement conditions and is unknown for the HORUS instrument. Concerning DOMINO, as this interference only affects the $\mathrm{HO}_{2}$ data, it could explain the $\left[\mathrm{HO}_{2}\right] /\left[\mathrm{RO}_{2}^{*}\right]=1$ in some of the air masses as to be $\left[\mathrm{HO}_{2}^{*}\right] /\left[\mathrm{RO}_{2}^{*}\right]$. From the interfering substances investigated by Fuchs et al. (2011) only benzene and isoprene were measured during DOMINO.

Concerning DUALER, the response of the PeRCA technique to a wide range of radicals has been proved to be very similar (Ashbourn et al., 1998). The effective chain length used for the calculation of the $\mathrm{RO}_{2}^{*}$ might change significantly with the set up as the result of peroxy radical losses, especially $\mathrm{HO}_{2}$, before the amplification zone, which depend on the material and shape of the reactor. This can lead to an underestimation of the total sum of radicals. Laboratory experiments using different $\mathrm{HO}_{2}+\mathrm{RO}_{2}$ mixtures indicated that for $50 \% \mathrm{HO}_{2}$ in the air mass, $\mathrm{RO}_{2}^{*}$ is $15 \%$ underestimated by the DUALER reactor used for DOMINO. There is no information available about the composition of the sampled peroxy radical mixture. Therefore, no correction was applied to the $\mathrm{RO}_{2}^{*}$ data. If the load of organic peroxy radicals with low wall loss rates is very high compared to $\mathrm{HO}_{2}, \mathrm{RO}_{2}^{*}$ can be significantly underestimated. This, together with the artificially increased $\left[\mathrm{HO}_{2}\right]$ due to the LIF interference can occasionally lead to $\left[\mathrm{HO}_{2}^{*}\right] /\left[\mathrm{RO}_{2}^{*}\right]$ ratios higher than 1 in very polluted air masses. Overall the analysis of the $\mathrm{HO}_{2} / \mathrm{RO}_{2}^{*}$ ratio should therefore rather be considered as qualitative.

Furthermore, the $\mathrm{HO}_{2}^{*} / \mathrm{RO}_{2}^{*}$ relative abundance was investigated in relation to the $\mathrm{OH}$ reactivities measured during DOMINO by Sinha et al. (2012). Generally, the fraction of $\mathrm{HO}_{2}^{*}$ in $\mathrm{RO}_{2}^{*}$ slightly increases as the $\mathrm{OH}$ reactivity increases (Fig. 13) and the $\mathrm{HO}_{2}^{*} / \mathrm{RO}_{2}^{*}$ ratio remains between 0.05 and 0.15 . The highest $\mathrm{OH}$ reactivities $\left(\approx 50-60 \mathrm{~s}^{-1}\right)$ are related to air masses within the continental sector (Fig. 14), and generally associated with highest $\mathrm{RO}_{2}^{*}$ levels, except for some radical plume events. Air masses affected by emissions of the Huelva industry and of ship traffic, as in the nighttime urban and ocean sector, respectively, present lower but still significant $\mathrm{OH}$ reactivity ( $\approx 10-30 \mathrm{~s}^{-1}$ and $2-10 \mathrm{~s}^{-1}$, respectively).

The chemical heterogeneity of the air masses within the urban-industrial sector which comprises a large number of industrial emission sources is reflected in the broad range of $\mathrm{RO}_{2}^{*}, \mathrm{HO}_{2}^{*}$, mixing ratios and $\mathrm{OH}$ reactivities (Fig. 14). In particular, the $\mathrm{OH}$ reactivity values support the idea suggested by the $\left[\mathrm{RO}_{2}\right]_{n s s}$ calculated from $\mathrm{NO}_{3}$ and estimated from a potential mixture of alkenes (Sect. 3.3) of high nocturnal $\mathrm{RO}_{2}^{*}$ production through ozonolysis of unmeasured reactive organic compounds arriving to the site.

\section{Summary and conclusions}

Free radical chemistry was investigated under mild weather conditions in late autumn at a coastal site influenced by emissions of weak biogenic and strong urban-industrial origin. Maximum diurnal peroxy radical mixing ratios ranged from 
(a)

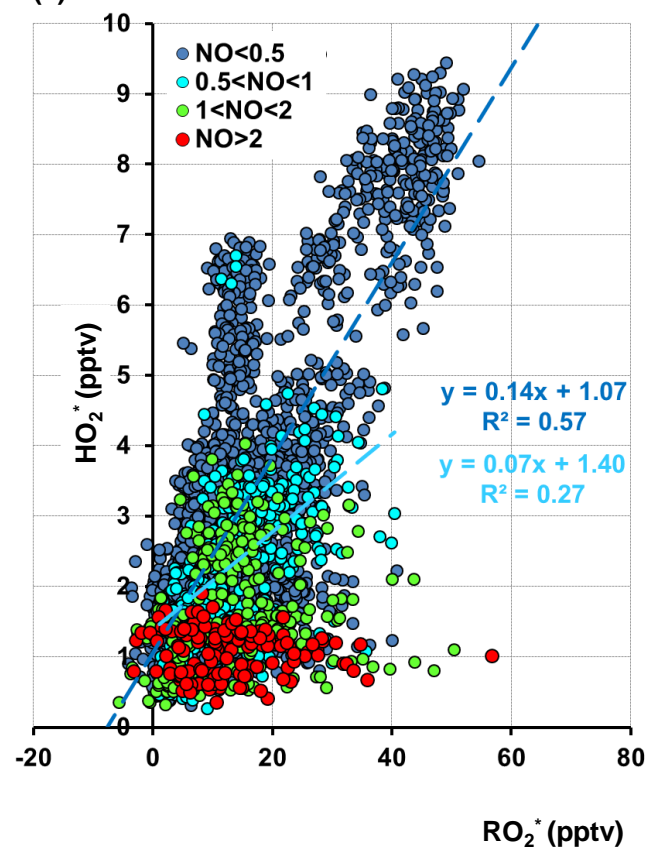

(b)

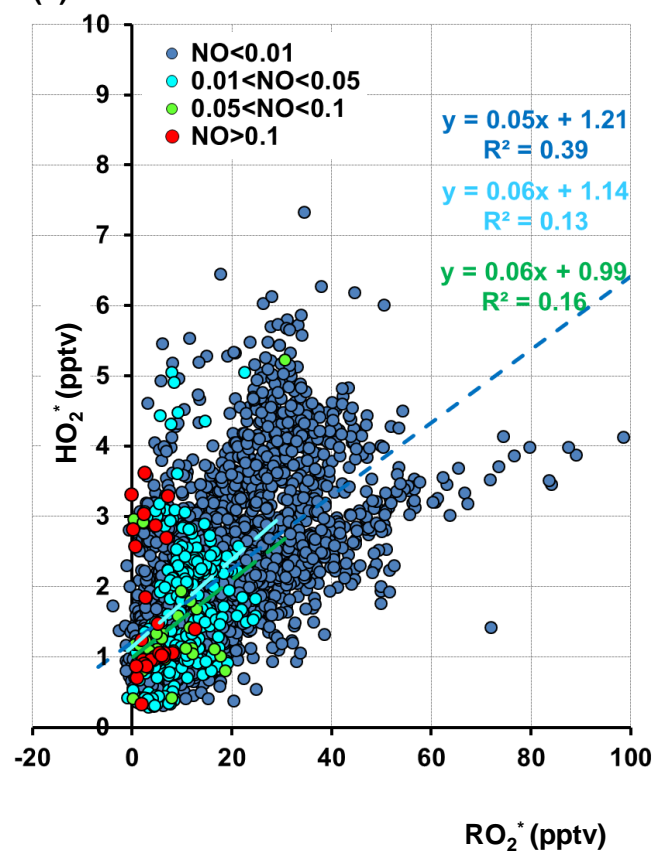

Fig. 12. $\mathrm{HO}_{2}^{*}$ versus $\mathrm{RO}_{2}^{*}$ for different $\mathrm{NO}$ mixing ratios (NO in ppbv) measured during DOMINO. Data for (a) photochemical (06:0017:00 UTC) and (b) non-photochemical (00:00-06:00 and 17:00 to 24:00 UTC) radical production are plotted separately.

(a)

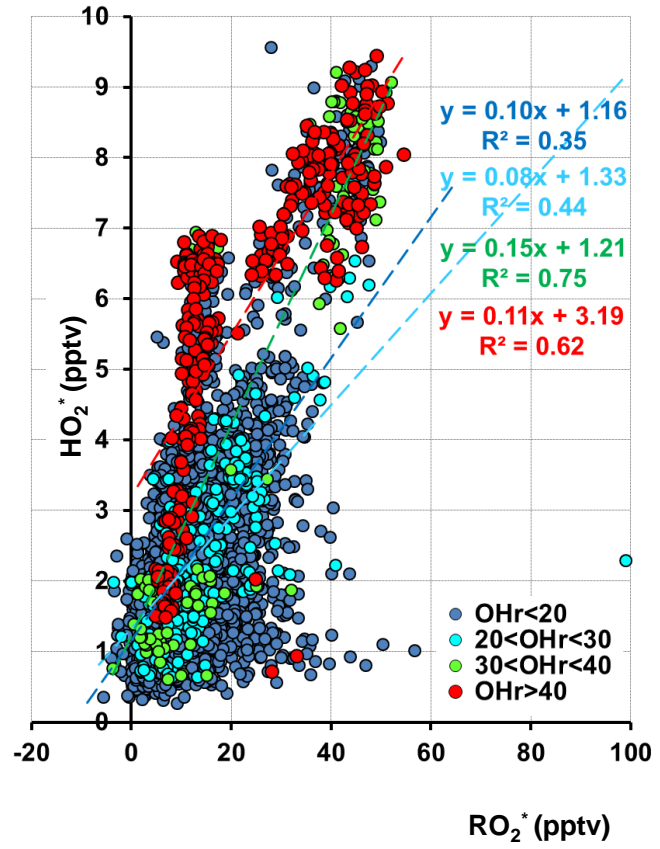

(b)

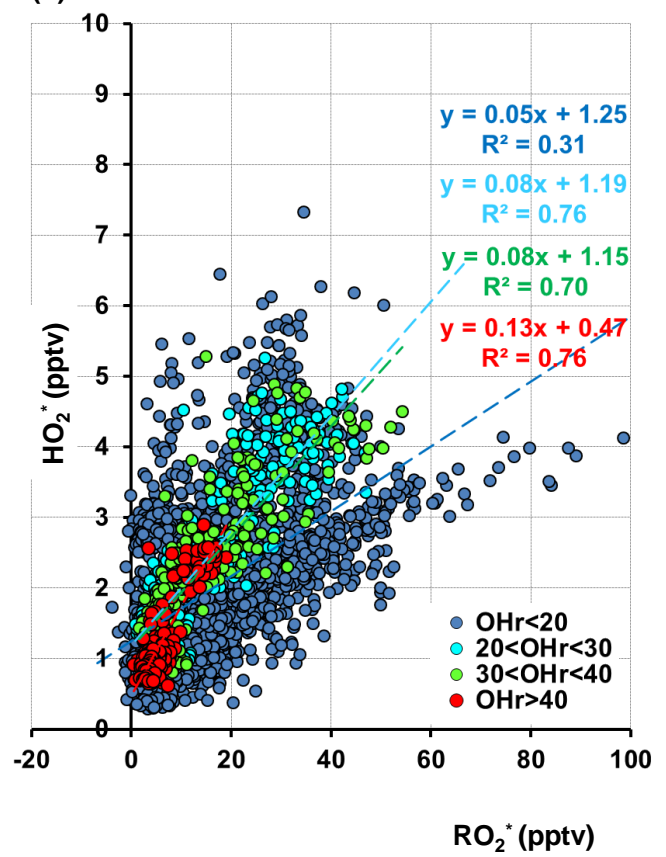

Fig. 13. $\mathrm{HO}_{2}^{*}$ versus $\mathrm{RO}_{2}^{*}$ for different $\mathrm{OH}$ reactivities $\left(\mathrm{OHr}\right.$ in $\left.\mathrm{s}^{-1}\right)$ measured during DOMINO. Data for (a) photochemical (06:0017:00 UTC) and (b) non-photochemical (00:00-06:00 and 17:00 to 24:00 UTC) radical production are plotted separately.

10 to 50 pptv. Very significant nocturnal $\mathrm{RO}_{2}^{*}$ were observed, with peak mixing ratios (up to $80 \mathrm{pptv}$ ) mostly associated with the arrival of VOC emission plumes of industrial ori- gin to the site. Reactions of $\mathrm{NO}_{3}$ with VOCs were a significant source of nighttime organic peroxy radicals. On average, calculated $\left[\mathrm{RO}_{2}\right]_{\mathrm{nss}}$ can account for between $47 \pm 16 \%$ and 
(a)
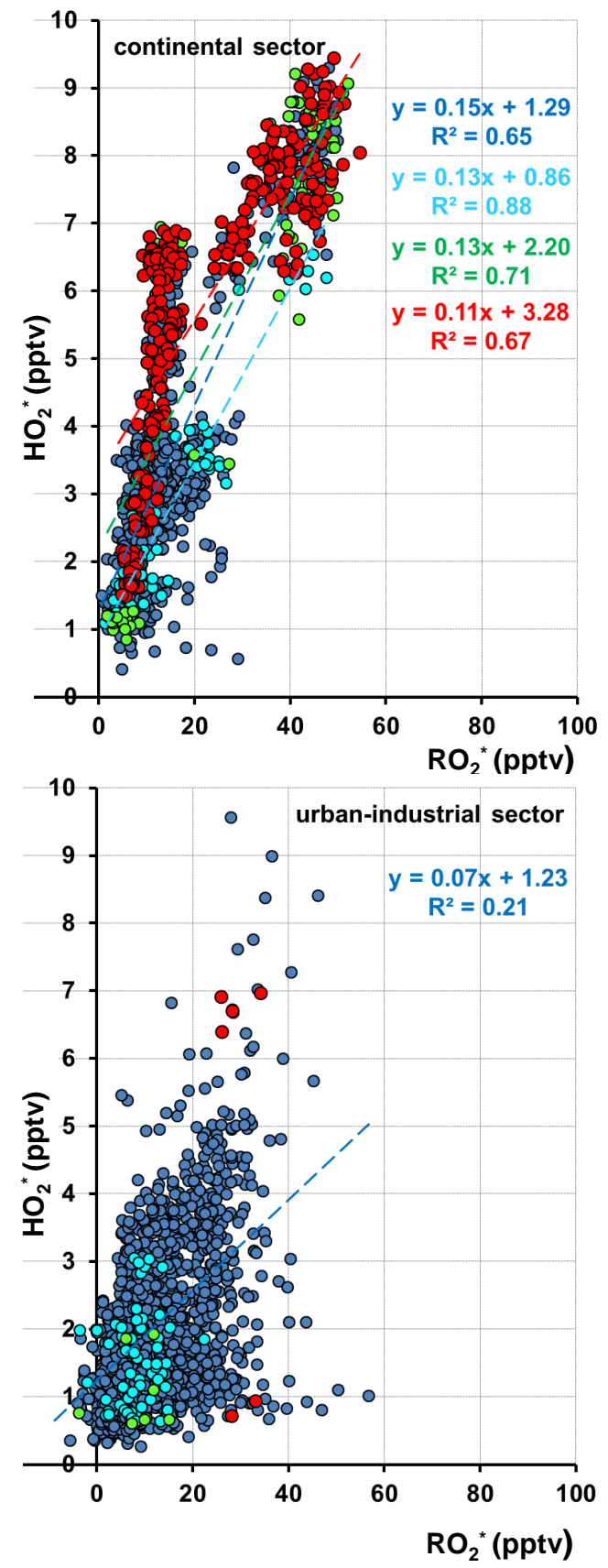

(b)
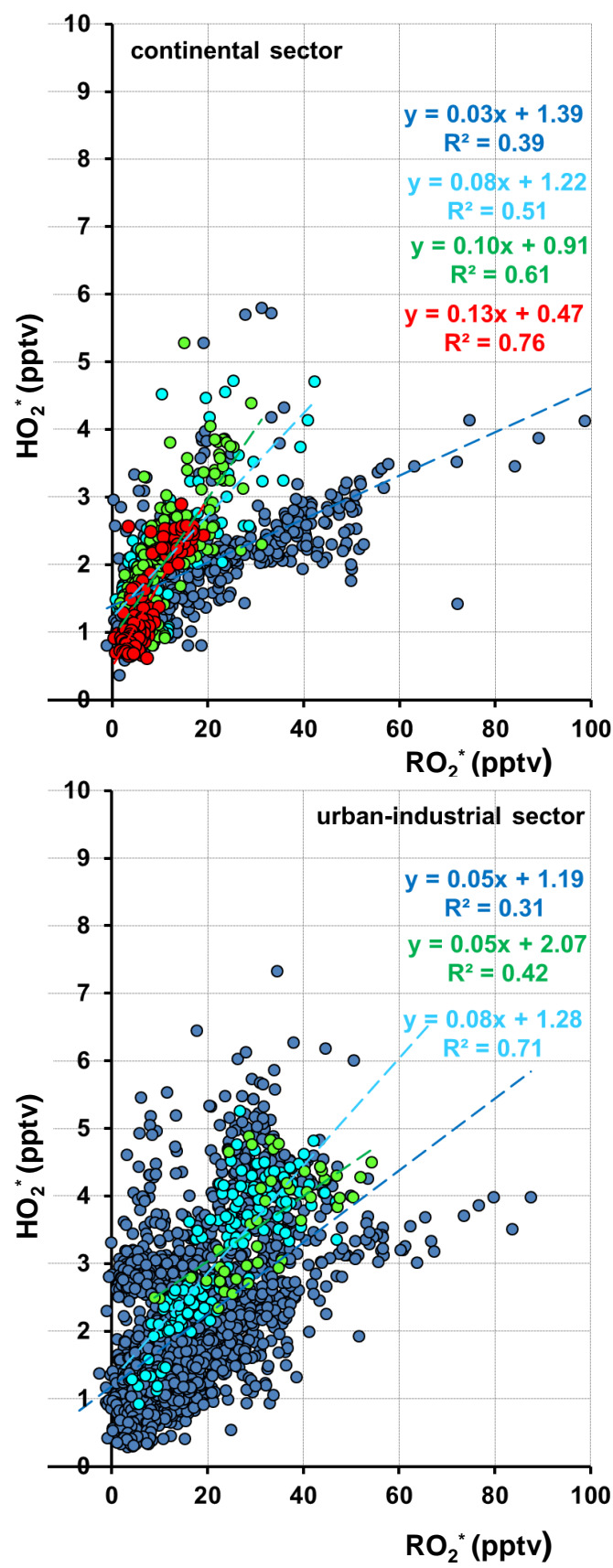

- $\mathrm{OHr}<20 \circ 20<\mathrm{OHr}<30 \circ 30<\mathrm{OHr}<40 \circ \mathrm{OHr}>40$

Fig. 14. $\mathrm{HO}_{2}^{*}$ versus $\mathrm{RO}_{2}^{*}$ for different $\mathrm{OH}$ reactivities $\left(\mathrm{OHr}\right.$ in $\left.\mathrm{s}^{-1}\right)$ measured during DOMINO within the urban-industrial and continental sectors. Data for (a) photochemical (06:00-17:00 UTC) and (b) non-photochemical (00:00-06:00 and 17:00 to 24:00 UTC) radical production are plotted separately.

$54 \pm 17 \%$ of the $\mathrm{RO}_{2}^{*}$ measured on those nocturnal periods with available $\mathrm{NO}_{3}$ data. During peak events at the highest measured VOC of anthropogenic industrial origin the estimated radical production from $\mathrm{NO}_{3}$ reactions cannot account for the measured concentration levels, indicating the impor- tance of other radical formation mechanisms such as ozonolysis of alkenes.

As measurements of neither anthropogenic alkenes nor nocturnal $\mathrm{OH}$ during the campaign are available, the significance of $\mathrm{O}_{3}$ and $\mathrm{VOC}$ reactions as $\mathrm{RO}_{2}$ source was indirectly 
evaluated by assuming a mixture of alkenes on the basis of literature data for emissions of industrial petrochemical origin and of benzene measurements at the site. The results indicate that the $\mathrm{RO}_{2}^{*}$ levels observed in most nocturnal events associated with emissions arriving from the urbanindustrial sector were consistent with generation via ozonolysis of alkenes.

The $\mathrm{HO}_{2}^{*} / \mathrm{RO}_{2}^{*}$ ratio derived from $\mathrm{RO}_{2}^{*}$ PeRCA and $\mathrm{HO}_{2}$ LIF measurements usually remained between $0.3-0.4$ in all wind directions, was slightly higher during nighttime, and close to 0.6 in air masses originating from the continental sector. However, this analysis and the corresponding calculated $\mathrm{HO}_{2} / \mathrm{RO}_{2}$ ratios must be rather considered as qualitative since the combined effect of $\left[\mathrm{RO}_{2}^{*}\right]$ underestimations and $\left[\mathrm{HO}_{2}\right]$ overestimations by DUALER and HORUS, respectively, can be of significance in very polluted air masses.

According to the general variation of $\mathrm{HO}_{2}^{*} / \mathrm{RO}_{2}^{*}$ with $\mathrm{OH}$ reactivity, air masses with higher content in organic peroxy radicals, mainly affected by industrial or ship emissions, are associated with significant $\mathrm{OH}$ reactivities $\left(\approx 10 \mathrm{~s}^{-1}\right)$. This, in turn, substantiates the importance of the nocturnal production of peroxy radicals from the ozonolysis of non-measured VOCs during DOMINO.

\section{Supplementary material related to this article is available online at: http://www.atmos-chem-phys.net/13/ 5731/2013/acp-13-5731-2013-supplement.pdf.}

Acknowledgements. The IUP-UB members would like to thank the Spanish National Institute of Aerospace Technology (INTA) for hosting the campaign, as well as to all the DOMINO participants providing measurements to the DOMINO data base. The first author acknowledges funding and support by MPI-Mainz, the University of Bremen, the state of Bremen and the HALO - SPP 1294 (Atmospheric and Earth system research) grant from the DFG (Deutsche Forschungsgemeinschaft).

Edited by: A. Hofzumahaus

\section{References}

Andrés Hernández, M. D., Burkert, J., Reichert, L., Stöbener, D., Meyer-Arnek J., Burrows, J. P., Dickerson, R. R., and Doddridge, B.: Marine boundary layer peroxy radical chemistry during the AEROSOLS99 campaign: measurements and analysis, J. Geophys. Res, 106, 20833-20846, doi:10.1029/2001JD900113, 2001.

Andrés-Hernández, M. D., Stone, D., Brookes, D. M., Commane, R., Reeves, C. E., Huntrieser, H., Heard, D. E., Monks, P. S., Burrows, J. P., Schlager, H., Kartal, D., Evans, M. J., Floquet, C. F. A., Ingham, T., Methven, J., and Parker, A. E.: Peroxy radical partitioning during the AMMA radical intercomparison exercise, Atmos. Chem. Phys., 10, 10621-10638, doi:10.5194/acp10-10621-2010, 2010.
Ashbourn, S. F. M., Jenkin, M. E., and Clemitshaw, K. C.: Laboratory studies of the response of a peroxy radical chemical amplifier to $\mathrm{HO}_{2}$ and a series of organic peroxy radicals, J. Atmos. Chem., 29, 233-266, 1998.

Bey, I., Aumont, B., and Toupance, G.: A modelling study of the nighttime radical chemistry in the lower continental troposphere 1. development of a detailed mechanism including nightime chemistry, J. Geophys. Res., 106, 9991-10001, 2001a.

Bey, I., Aumont, B., and Toupance, G.: A modelling study of the nighttime radical chemistry in the lower continental troposphere 2. origin and evolution of $\mathrm{HO}_{\mathrm{x}}$, J. Geophys. Res., 106, 999110001, 2001b.

Brown, S. S. and Stutz, J.: Nighttime radical observations and chemistry, Chem. Soc. Rev., 41, 6405-6447, 2012.

Burkert, J., Andrés Hernández, M. D., Stöbener D., Burrows, J. P., Weissenmayer M., and Kraus, A.: Peroxy radical and related trace gas measurement in the marine boundary layer above the Atlantic Ocean, J. Geophys. Res, 106, 5457-5477, doi:10.1029/2000JD900613, 2001a.

Burkert, J., Behmann, T., Andrés Hernández, M. D., Weißenmayer, M., Perner, D., and Burrows, J. P.: Measurements of peroxy radicals in a forested area in Portugal, Chemosphere - Global Change Sci., 3, 3327-3338, 2001b.

Burkert, J., Andrés Hernández, M. D., Reichert, L., Stöbener, D., Meyer-Arnek, J., Burrows, J. P, Mühle, J., Zahn, A., Carsey, T., Dickerson, R. R., and Doddridge, B.: Trace gas and radical behaviour in the marine boundary layer during INDOEX 1999, J. Geophys. Res., 108, 8000, doi:10.1029/2002JD002790, 2003.

Calvert, J. G., Mellouki, A., Orlando, J. J., Pilling M. J., and Wallington T. J.: The mechanisms of atmospheric oxidation of the oxygenates, Oxford University Press, New York, USA, 2011.

Cantrell, C. A., Shetter, R. E., and Calvert, J. G.: Dual-Inlet chemical amplifier for atmospheric peroxy radical measurements, Anal. Chem., 68, 4194-4199, 1996.

Carpenter, L. J., Clemitshaw, K. C., Burgess, R. A., Penkett, S. A., Caper, J. N, and McFadyen, G. G.: Investigation and evaluation of the $\mathrm{NO}_{\mathrm{x}} / \mathrm{O}_{3}$ photochemical steady state, Atmos. Environ., 32, 3353-3365, 1998.

Carslaw, N., Carpenter, L. J., Plane, J. M. C., Allan, B. J., Burgess, R. A., Clemitshaw, K. C., Coe, H., and Penkett, S. A.: Simultaneous observations of nitrate and peroxy radicals in the marine boundary layer, 1 . Model construction and comparison with field measurements, J. Geophys. Res., 102, 18917-18933, 1997.

Carslaw, N., Creasey, D. J., Heard, D. E., Jacobs, P., Lee, J. D. L., Lewis, A. C., McQuaid, J. B., Pilling, M. J., Bauguitte, S., Penkett, S. A., Monks, P. S., and Salisbury, G.: Eastern Atlantic Spring Experiment 1997 (EASE97) - 2. Comparisons of model concentrations of $\mathrm{OH}, \mathrm{HO}_{2}$, and $\mathrm{RO}_{2}$ with measurements, J. Geophys. Res., 107, 4190, 10.1029/201JD001568, 2002.

Carter, W. P. L.: A detailed mechanism for the gas-phase atmospheric reations of organic compounds, Atmos. Environ., A24, 481-518, 1990.

Crowley, J., Thieser, J., Tang M. J., Schuster, G., Bozem, H., Beygi, Z. H., Fischer, H.,Diesch, J.-M., Drewnick, F., Borrmann, S., Song, W., Yassaa, N., Williams, J., Pöhler, D., Platt, U., and Lelieveld, J.: Variable lifetimes and loss mechanisms for $\mathrm{NO}_{3}$ and $\mathrm{N}_{2} \mathrm{O}_{5}$ during the DOMINO campaign: Contrasts between marine, urban and continental air, Atmos. Chem. Phys., 11, 10853-10870, doi:10.5194/acp-11-10853-2011, 2011. 
Crowley, J. N., Schuster, G., Pouvesle, N., Parchatka, U., Fischer, H., Bonn, B., Bingemer, H., and Lelieveld, J.: Nocturnal nitrogen oxides at a rural mountain-site in south-western Germany, Atmos. Chem. Phys., 10, 2795-2812, doi:10.5194/acp-10-27952010, 2010.

Diesch, J.-M., Drewnick, F., Zorn, S. R., von der WeidenReinmüller, S. L., Martinez, M., and Borrmann, S.: Variability of aerosol, gaseous pollutants and meteorological characteristics associated with changes in air mass origin at the SW Atlantic coast of Iberia, Atmos. Chem. Phys., 12, 3761-3782, 2012, doi:10.5194/acp-12-3761-2012, 2012.

Dillon, T. J. and Crowley, J. N.: Direct detection of $\mathrm{OH}$ formation in the reactions of $\mathrm{HO}_{2}$ with $\mathrm{CH}_{3} \mathrm{C}(\mathrm{O}) \mathrm{O}_{2}$ and other substituted peroxy radicals, Atmos. Chem. Phys., 8, 4877-4889, doi:10.5194/acp-8-4877-2008, 2008.

Draxler, R. R. and Rolph, G. D.: HYSPLIT (HYbrid Single-Particle Lagrangian Integrated Trajectory). Model access via NOAA (http://ready.arl.noaa.gov/HYSPLIT.php), NOAA Air Resources Laboratory, Silver Spring, MD, USA, 2011.

Emmerson, K. M., Carslaw, N., and Pilling, M. J.: Urban atmospheric chemistry during the PUMA campaign. 2: radical budgets for $\mathrm{OH}, \mathrm{HO}_{2}$ and $\mathrm{RO}_{2}$, J. Atmos. Chem., 52, 165-183, 2005.

Finlayson-Pitts, B. J. and Pitts, J. N.: Chemistry of the Upper and Lower Atmosphere: Theory, Experiments, and Applications, Academic Press, 179-263, 2000.

Fleming, Z. L., Monks, P. S., Rickard, A. R., Heard, D. E., Bloss, W., Seakins, P. W., Still, T. J., Sommariva, R., Pilling, M. J., Morgan, R., Green, T. J., Brough, N., Mills, G. P., Penkett, S. A., Lewis, A. C., Lee, J. D. L., Saiz-Lopez, A., and Plane, J. M. C.: Peroxy radical chemistry and the control of ozone photochemistry at Mace Head, Ireland during the summer of 2002, Atmos. Chem. Phys., 6, 2193-2214, doi:10.5194/acp-6-2193-2006, 2006a.

Fleming, Z. L., Monks, P. S., Rickard, A. R., Bandy, B. J., Brough, N., Green, T. J., Reeves, C. E., and Penkett, S. A.: Seasonal dependence of peroxy radical concentrations at a Northern hemisphere marine boundary layer site during summer and winter: evidence for radical activity in winter, Atmos. Chem. Phys., 6, 5415-5433, doi:10.5194/acp-6-5415-2006, 2006b.

Fuchs, H., Bohn, B., Hofzumahaus, A., Holland, F., Lu, K. D., Nehr, S., Rohrer, F., and Wahner A.: Detection of $\mathrm{HO}_{2}$ by laserinduced fluorescence: calibration and interferences from $\mathrm{RO}_{2}$ radicals, Atmos. Meas. Tech., 4, 1209-1225, doi:10.5194/amt4-1209-2011, 2011.

Geyer, A., Bachmann, K., Hofzumahaus, A., Holland, F., Konrad, S., Klüpfel, T., Pätz, H. W., Perner, D., Mihelcic, D., Schäfer, H. J., Volz-Thomas, A., and Platt, U.: Nighttime formation of peroxy and hydroxyl radicals during the BERLIOZ campaign: Observations and modeling studies, J. Geophys. Res. 108, 8249, doi:10.1029/2001JD000656, 2003.

Griffin, R. J., Beckman, P. J., Talbot, R. W., Sive, B. C., and Varner, R. K.: Deviations from ozone photostationary state during the International Consortium for Atmospheric Research on Transport and Transformation 2004 campaign: Use of measurements and photochemical modeling to assess potential causes, J. Geophys. Res. 112, D10807, doi:10.1029/2001JD000656, 2007.

Harrison, R. M., Yin, J., Tilling, R. M., Cai, X., Seakins, P. W., Hopkins, J., Lansley D., Lewis, A. C., Hunter, M. C., Heard, D. E., Carpenter, L. J., Creasy, D. J., Lee, J. D. L., Pilling, M.
J., Carslaw, N., Emmerson K. M., Redington, A., Derwent, R. G., Ryall, D., Mills, G., and Penkett, S. A.: Measurement and modelling of air pollution and atmospheric chemistry in the UK West Midlands conurbation: Overview of the PUMA Consortium project, Sci. Total Environ., 360, 5-25, 2006.

Heard, D. E., Carpenter, L. J., Creasey, D. J., Hopkins, J. R., Lee, J. D., Lewis, A. C., Pilling, M. J., Seakins, P. W., Carslaw, N., and Emmerson, K. M.: High levels of the hydroxyl radical in the winter urban troposphere, Geophys. Res. Lett., 31, L18112, doi:10.1029/2004GL020544, 2004.

Hofzumahaus, A, Rohrer, F., Lu, K., Bohn, B., Brauers, T., Chang, C., Fuchs, H., Holland, F., Kita, K., Kondo, Y., Li, X., Lou, S., Shao, M., Zeng, L., Wahner, A., and Zhang, Y.: Amplified trace gas removal in the troposphere, Science, doi:10.1126/science.1164566, 2009.

Holloway, A. M. and Wayne, R. P.: Atmospheric Chemistry, Roy. Soc. Chem., ISBN: 978-1-84755-807-7, 260 pp., 2010.

Hosaynali Beygi, Z., Fischer, H., Harder, H. D., Martinez, M., Sander, R., Williams, J., Brookes, D. M., Monks, P. S., and Lelieveld, J.: Oxidation photochemistry in the Southern Atlantic boundary layer: unexpected deviations of photochemical steady state, Atmos. Chem. Phys., 11, 8497-8513, doi:10.5194/acp-118497-2011, 2011.

Jensen, N. R., Hjorth, J., Lohse, C., Skov, H., and Restelli, G.: Products and mechanisms of the gas-phase reactions of $\mathrm{NO}_{3}$ with $\mathrm{CH}_{3} \mathrm{SCH}_{3}, \mathrm{CD}_{3} \mathrm{SCD}_{3}, \mathrm{CH}_{3} \mathrm{SH}$ and $\mathrm{CH}_{3} \mathrm{SSCH}_{3}$, J. Atmos. Chem., 14, 95-108, 1992.

Kanaya, Y., Nakamura, S., Matsumoto, J., Tanimoto, H., and Akimoto, $\mathrm{H}$.: Nighttime variations in $\mathrm{HO}_{2}$ radical mixing ratios at Rishiri Island observed with elevated monoterpene mixing ratios, Atmos. Environ., 36, 4929-4940, 2002.

Kanaya, Y., Cao, R., Kato, S., Miyakawa, Y., Kajii, Y., Tanimoto, H., Yokouchi, Y. Mochide, M., Kawamura, K., and Akimoto, H.: Chemistry of $\mathrm{OH}$ and $\mathrm{HO}_{2}$ radicals observed at Rishiri Island, Japan, in September 2003: Missing daytime sink of $\mathrm{HO}_{2}$ and positive nighttime correlations with monoterpenes, J. Geophys. Res., 112, D11308, doi:10.1029/2006JD007987, 2007.

Kanaya, Y., Fukuda, M., Akimoto, H., Takegawa, N., Komazaki, Y., Yokouchi, Y., Koike, M., and Kondo, Y: Urban photochemistry in central Tokyo: 2. Rates and regimes of oxidant $\left(\mathrm{O}_{3}\right.$ and $\left.\mathrm{NO}_{2}\right)$ production, J. Geophy. Res., 113, D06301, doi:10.1029/2007JD008671, 2008.

Kartal, D., Andrés-Hernández, M. D., Reichert, L., Schlager H., and Burrows, J. P.: Technical Note: Characterisation of a DUALER instrument for the airborne measurement of peroxy radicals during AMMA 2006, Atmos. Chem. Phys., 10, 3047-3062, doi:10.5194/acp-10-3047-2010, 2010.

Kelly, T. J. and Fortune, C. R.: Continuous monitoring of gaseous formaldehyde using an improved fluorescence approach, Int. J. Environ. Anal. Chem., 54, 249-263, 1994.

Kubistin, D., Harder, H., Martinez, M., Rudolf, M., Sander, R., Bozem, H., Eerdekens, G., Fischer, H., Gurk, C., Klüpfel, T., Königstedt, R., Parchatka, U., Schiller, C. L., Stickler, A., Taraborrelli, D., Williams, J., and Lelieveld, J.: Hydroxyl Radicals in the Tropical Troposphere over the Suriname Rain Forest: Comparison of Measurements with the Box Model MECCA, Atmos. Chem. Phys., 10, 9705-9728, doi:10.5194/acp-10-97052010, 2010. 
Leighton, P. A.: Photochemistry of Air Pollution, Academic Press, San Diego, CA, USA, BCIN Number 63752, 1961.

Lelieveld, J., Butler, T. M., Crowley, J. N., Dillon, T. J., Fischer, H., Ganzeveld, L., Harder, H., Lawrence, M. G., Martinez, M., Taraborrelli, D., and Williams, J.: Atmospheric oxidation capacity sustained by a tropical forest, Nature, 452, 737-740, 2008.

Leuchner, M. and Rappenglück, B.: VOC source-receptor relationships in Houston during TexAQS-II, Atmos. Environ., 44, 40564067, 2010.

Lightfoot, P. D., Cox, R. A., Crowley, J. N., Destriau, M., Hayman, G. D., Jenkin, M. E., Moortgat, G. K., and Zabel, F.: Organic peroxy radicals: kinetics, spectroscopy and tropospheric chemistry, Atmos. Environ., 26, 1805-1961, 1992.

Mannschreck, K., Gilge, S., Plass-Dülmer, C., Fricke, W., and Berresheim, H.: Assessment of the applicability of $\mathrm{NO}-\mathrm{NO}_{2}$ $\mathrm{O}_{3}$ photostationary state to long-term measurements at the Hohenpeissenberg GAW station, Germany, Atmos. Chem. Phys., 4, 1265-1277, doi:10.5194/acp-4-1265-2004, 2004.

Martinez, M., Harder, H., Kovacs, T. A., Simpas, J. B., Bassis, J., Lesher, R., Brune, W. H., Frost, G. J., Williams, E. J., Stroud, C. A., Jobson, B. T., Roberts, J. M., Hall, S. R., Shetter, R. E., Wert, B., Fried, A., Alicke, B., Stutz, J., Young, V. L., White, A. B., and Zamora, R. J.: $\mathrm{OH}$ and $\mathrm{HO}_{2}$ concentrations, sources, and loss rates during the Southern oxidants study in Nashville, Tennessee, summer 1999, J. Geophys. Res., 108, 4617, doi:10.1029/2003JD003551, 2003.

Martinez, M., Harder, H., Kubistin, D., Rudolf, M., Bozem, H., Eerdekens, G., Fischer, H., Klüpfel, T., Gurk, C., Königstedt, R., Parchatka, U., Schiller, C. L., Stickler, A., Williams, J., and Lelieveld, J.: Hydroxyl radicals in the tropical troposphere over the Suriname rainforest: airborne measurements, Atmos. Chem. Phys., 10, 3759-3773, doi:10.5194/acp-10-3759-2010, 2010.

Mihelcic, D., Klemp, D., Müsgen, P., Pätz, H. W., and VolzThomas, A.: Simultaneous measurements of peroxy and nitrate radicals at Schauinsland, J. Atmos. Chem., 16, 313-335, 1993.

Mihele, C. M. and Hastie, D. R.: The sensitivity of the radical amplifier to ambient water vapour, Geophys. Res. Lett., 25, 19111913, 1998.

Mihele, C. M., Mozurkewich, M., and Hastie, D. R.: Radical loss in a chain reaction of $\mathrm{CO}$ and $\mathrm{NO}$ in the presence of water: Implications for the radical amplifier and atmospheric chemistry, Intern. J. Chem. Kinetics, 31, 145-152, 1999.

Monks, P. S.: Gas-phase radical chemistry in the troposphere, Chem. Soc. Rev., 34, 376-395, 2005.

Orlando, J. J. and Tyndall, G. S.: Laboratory studies of organic peroxy radical chemistry: an overview with emphasis on recent issues of atmospheric significance, Critical Review, Chem Soc. Rev., 41, 6294-6317, 2012.

Paulson, S. E. and Orlando, J. J.: The reactions of ozone with alkenes: An important source of $\mathrm{HO}_{\mathrm{x}}$ in the boundary layer, Geophys. Res. Letters, 23, 25, 3727-3730, 1996.

Penkett, S. A., Clemitshaw, K. C., Savage, N. H., Burgess, R. A., Cardenas, L. M., Carpenter, L. J., McFadyen, G. G., and Cape, J. N.: Studies of oxidant production at the Weybourne Atmospheric Observatory in summer and winter conditions, J. Atmos. Chem., 33, 111-128, 1999.

Platt, U., Perner, D., Schröder, H., Kessler, G., and Tönissen, A.: The diurnal variation of $\mathrm{NO}_{3}$, J. Geophys. Res., 86, 1196511970, 1981.
Platt, U., LeBras, G., Poulet, Burrows, J. P., and Moortgat, G.: Peroxy radicals from night-time reaction of $\mathrm{NO}_{3}$ with organic compounds, Nature, 348, 147-149, doi:10.1038/348147a0, 1990.

Platt, U., Alicke, B., Dubois, R., Geyer, A., Hofzumahaus, A., Holland, F., Martínez, M., Mihelcic, D., Klüpfel, T., Lohrmann, B., Pätz, W., Perner, D., Rohrer, F., Schäfer, J., and Stutz, J.: Free radicals and fast photochemistry during BERLIOZ, J. Atmos. Chem., 42, 359-394. 2002.

Reichert, L., Andrés Hernández, M. D., Stöbener, D., Burkert, J., and Burrows, J. P.: Investigation of the effect of water complexes in the determination of peroxy radical ambient concentrations: implications for the atmosphere, J. Geophys. Res, 108, 40174032, 2003.

Ren, X., Harder, H., Martinez, M., Faloona, I., Tan, D., Lesher, R. L., DiCarlo, P., Simpas, J. B., and Brune, W. H.: Interference testing for atmospheric $\mathrm{HO}_{\mathrm{x}}$ measurements by laser-induced fluorescence, J. Atmos. Chem., 47, 169-190, 2004.

Ren, X., Brune, W. H., Mao, J., Mitchell, M. J., Lesher, R. L., Simpas, J. B., Metcall, A. R., Schwab, J. J., Cai, C., Li, Y., Demerjian, K. L., Felton, H. D., Boynton, G., Adams, A., Perry, J., He, Y., Zhou, X., and Hou, J.: Behavior of $\mathrm{OH}$ and $\mathrm{HO}_{2}$ in the winter atmosphere in New York City, Atmos. Environ., 40, S252-S263, 2006.

Sadanaga, Y., Matsumoto, J., and Kajii, Y.: Photochemical reactions in the urban air: Recent understandings of radical chemistry, J. Photoch. Photobio. C, 4, 85-104, doi:10.1016/S13895567(03)00006-6, 2003.

Salisbury, G., Richard, A. R, Monks, P. S, Allan, B. J., Bauguitte, S., Penkett, S. A., Carslaw, N., Lewis, A. C., Creasey, D. J., Heard, D. E., Jacobs, P. J., and Lee, J. D.: Production of peroxy radicals at night via reactions of ozone and the nitrate radical in the marine boundary layer, J. Geophys. Res., 106, 12669-12687, 2001.

Sander, S. P., Friedl, R. R., Barker, J. R., Golden, D. M., Kurylo, M. J., Wine, P. H, Abbatt, J. P. D., Burkholder, J. B., Kolb, C. E., Moortgat, G. K., Huie, R. E., and Orkin, V. L.: Chemical Kinetics and Photochemical Data for Use in Atmospheric Studies Evaluation Number 17, JPL publication 10-6, Jet Propulsion Laboratory, 2011.

Sinha, V., Williams, J., Crowley, J. N., and Lelieveld, J.: The Comparative Reactivity Method - a new tool to measure total $\mathrm{OH}$ Reactivity in ambient air, Atmos. Chem. Phys., 8, 2213-2227, doi:10.5194/acp-8-2213-2008, 2008.

Sinha, V., Williams, J., Diesch, J. M., Drewnick, F., Martinez, M., Harder, H., Regelin, E., Kubistin, D., Bozem, H., HosaynaliBeygi, Z., Fischer, H., Andrés-Hernández, M. D., Kartal, D., Adame, J. A., and Lelieveld, J.: Constraints on instantaneous ozone production rates and regimes during DOMINO derived using in-situ $\mathrm{OH}$ reactivity measurements, Atmos. Chem. Phys., 12, 7269-7283, doi:10.5194/acp-12-7269-2012, 2012.

Sommariva, R., Pilling, M. J., Bloss, W. J., Heard, D. E., Lee, J. D., Fleming, Z. L., Monks, P. S., Plane, J. M. C., Saiz-Lopez, A., Ball, S. M., Bitter, M., Jones, R. L., Brough, N., Penkett, S. A., Hopkins, J. R., Lewis, A. C., and Read, K. A.: Night-time radical chemistry during the NAMBLEX campaign, Atmos. Chem. Phys., 7, 587-598, doi:10.5194/acp-7-587-2007, 2007.

Sommariva, R., Osthoff, H. D., Brown, S. S., Bates, T. S., Baynard, T., Coffman, D., de Gouw, J. A., Goldan, P. D., Kuster, W. C., Lerner, B. M., Stark, H., Warneke, C., Williams, E. J., Fehsen- 
feld, F. C., Ravishankara, A. R., and Trainer, M.: Radicals in the marine boundary layer during NEAQS 2004: a model study of day-time and night-time sources and sinks, Atmos. Chem. Phys., 9, 3075-3093, doi:10.5194/acp-9-3075-2009, 2009.

Song, W., Williams, J., Yassaa, N., Martinez, M., Carnero, J. A. A., Fernandez, P. H., Bozem, H., and Lelieveld, J.: Winter and summer characterization of biogenic enantiomeric monoterpenes and anthropogenic BTEX compounds at a Mediterranean Stone Pine forest site. J. Atmos. Chem., 68, 233-250, doi:10.1007/s10874012-9219-4, 2011.

Song, W., Williams, J., Yasaa, N., Regelin, E., Harder, H., MartínezHarder, M., Adame Carnero, J. A., Hidalgo, P. J., Bozem, H., and Lelieveld, J.: Characterisation of biogenic enantiomeric monoterpenes and anthropogenic BTEX compounds at a Mediterranean stone pine forest site in Southern Spain, Atmos. Chem. Phys. Discuss., in preparation, 2012.

Sörgel, M., Regelin, E., Bozem, H., Diesch, J. M., Drewnick, F., Fischer, H., Harder, H., Held, A., Hosaynali-Beygi, Z., Martinez, M., and Zetzsch, C.: Quantification of the unknown HONO daytime source and its relation to $\mathrm{NO}_{2}$, Atmos. Chem. Phys., 11, 10433-10447, doi:10.5194/acp-11-10433-2011, 2011.
Wayne, R. P., Barnes, I., Biggs, P., Burrows, J. P., Canosa-Mas, C. E., Hjorth, J., Le Bras, G., Moortgat, G. K., Perner, D., Poulet, G., Restelli, G., and Sidebottom, H.: The nitrate radical: physics, chemistry and the atmosphere, Atmos. Environ., 25A, 1-203, 1991.

Whalley, L. K., Furneaux, K. L., Goddard, A., Lee, J. D., Mahajan, A., Oetjen, H., Read, K. A., Kaaden, N., Carpenter, L. J., Lewis, A. C., Plane, J. M. C., Saltzman, E. S., Wiedensohler, A., and Heard, D. E.: The chemistry of $\mathrm{OH}$ and $\mathrm{HO}_{2}$ radicals in the boundary layer over the tropical Atlantic Ocean, Atmos. Chem. Phys., 10, 1555-1576, doi:10.5194/acp-10-1555-2010, 2010.

Whalley, L. K., Edwards, P. M., Furneaux, K. L., Goddard, A., Ingham, T., Evans, M. J., Stone, D., Hopkins, J. R., Jones, C. E., Karunaharan, A., Lee, J. D., Lewis, A. C., Monks, P. S., Moller, S. J., and Heard, D. E.: Quantifying the magnitude of a missing hydroxyl radical source in a tropical rainforest, Atmos. Chem. Phys., 11, 7223-7233, doi:10.5194/acp-11-7223-2011, 2011.

Winer, A. M., Atkinson, R., and Pitts Jr., J. N.: Gaseous nitrate radical: possible nighttime atmospheric sink for biogenic organic compounds, Science, 224, 156-158, 1984. 